\title{
O PODER LEGISLATIVO PARANAENSE NO CONTEXTO DA REVOLUÇÃO DE 1930: UM ESTUDO SOBRE OS CAPITAIS FAMILIARES E POLÍTICOS DOS DEPUTADOS FEDERAIS E ESTADUAIS (1930 A 1937)
}

\author{
Natália Cristina Granato ${ }^{2}$
}

\begin{abstract}
Resumo: O presente trabalho objetiva analisar as trajetórias políticas e os capitais familiares dos deputados federais e estaduais eleitos para as legislaturas de 1930 a 1935. O contexto analisado refere-se à Revolução de 1930. Nossa intenção é verificar de que maneira a Revolução de 1930 afetou a política paranaense e quais foram as continuidades e rupturas verificáveis nos levantamentos biográficos desses agentes políticos. A amostra de deputados abrangerá a análise do biênio de 1930-1931, cujos mandatos foram atravessados pelo Movimento de 1930 e interrompidos pelo processo revolucionário. Verificaremos se os agentes que compõe essa amostra tiveram continuidade nas carreiras políticas no decorrer da década de 1930, levantando informações de redes familiares e sociais dos quais os mesmos pertenciam. Outra parte da análise será composta pelos deputados federais eleitos para a Assembleia Nacional Constituinte, no ano de 1933 e os deputados estaduais eleitos para o exercício do mandato de 1935 a 1937, ano em que o golpe do Estado Novo fechou o poder legislativo nas esferas estadual e federal. Verificaremos quais eram as redes sociais e familiares destes agentes. A principal perspectiva teórica desse trabalho será a de Pierre Bourdieu nas suas considerações sobre o campo político e os capitais acumulados pelos seus agentes, que incluem, além dos capitais propriamente políticos, os capitais familiares, sociais, econômicos e intelectuais, que acumulam e incrementam suas posições na sociedade paranaense. Também refletiremos sobre a reprodução de posições na política por parte dos seus agentes, em momentos de inflexão política, como é o caso da Revolução de 1930.
\end{abstract}

Palavras-chave: Revolução de 1930. Política Paranaense. Poder Legislativo.

\section{THE LEGISLATIVE POWER OF PARANÁ IN THE CONTEXT OF THE REVOLUTION OF 1930: A STUDY ON THE FAMILY AND POLITICAL CAPITALS OF FEDERAL AND STATE DEPUTIES (1930 TO 1937)}

\begin{abstract}
This paper aims to analyze the political trajectories and family capitals of federal and state deputies elected to the legislatures from 1930 to 1935. The context analyzed refers to the Revolution of 1930. Our intention is to verify how the Revolution of 1930 affected the politics of Paraná and what were the continuities and ruptures verifiable in the biographical surveys of these political agents. The sample of deputies will cover the analysis of the biennium of 1930-1931, whose mandates were crossed by the 1930 Movement and interrupted by the revolutionary process. We will verify if the agents that compose this sample had continuity in the political careers during the decade of 1930, raising information of familiar and social networks of which they belonged. Another part of the analysis will be composed of the federal deputies elected to the National

\footnotetext{
1 Trabalho apresentado no X Seminário Nacional de Sociologia e Política, realizado em Curitiba (PR), nas dependências da Universidade Federal do Paraná, entre os dias 15 e 17 de maio de 2019.

${ }^{2}$ Doutoranda em Sociologia pela Universidade Federal do Paraná. Bacharela e Licenciada em Ciências Sociais e Mestra em Sociologia pela mesma instituição. Integrante do Núcleo de Estudos Paranaenses (NEP- UFPR). E-mail para contato: nataliagranato@ hotmail.com.
} 
Constituent Assembly in 1933 and the state deputies elected for the term of office from 1935 to 1937, the year in which the coup of the Estado Novo closed the legislative power in the state spheres and federal. We will check the social and family networks of these agents. The main theoretical perspective of this work will be that of Pierre Bourdieu in his considerations on the political field and the capital accumulated by his agents, which include, besides the political capitals, the family, social, economic and intellectual capitals that accumulate and increase their positions in the society of Paraná. We will also reflect on the reproduction of positions in politics by its agents, in moments of political inflection, as is the case of the Revolution of 1930.

Keywords: Revolution of 1930. Paranaense Politics. Legislative power.

\section{Introdução}

O presente trabalho objetiva analisar as trajetórias políticas e os capitais familiares dos deputados federais e estaduais eleitos para as legislaturas de 1930 a 1935 . A amostra de deputados abrangerá a análise do biênio de 1930-1931, cujos mandatos foram atravessados pelo Movimento de 1930 e interrompidos pelo processo revolucionário. Verificaremos se os agentes que compõe essa amostra tiveram continuidade nas carreiras políticas no decorrer da década de 1930, levantando informações de redes familiares e sociais dos quais os mesmos pertenciam. Outra parte da análise será composta pelos deputados federais eleitos para a Assembleia Nacional Constituinte, no ano de 1933 e os deputados estaduais eleitos para o exercício do mandato de 1935 a 1937, ano em que o golpe do Estado Novo fechou o poder legislativo nas esferas estadual e federal. Verificaremos quais eram as redes sociais e familiares destes agentes, comparando-as com a legislatura anterior ao movimento revolucionário, e também analisaremos os capitais políticos dos mesmos, verificando o desenrolar das suas trajetórias políticas nas décadas de 1930 e 1940.

Em linhas gerais, a política local no período anterior a 1930 é caracterizada pelo monopólio exclusivo do Partido Republicano Paranaense sobre postos e cargos nas variadas instâncias de poder, constatando-se também a inexistência de oposições partidárias. Tal quadro é uma realidade desde a Coligação Republicana de 1908, que reuniu membros do Partido Republicano Federal e a União Republicana (GOULART, 2004; DAGOSTIM, 2011).

Esse cenário começou a se modificar com a ascensão de movimentos críticos às oligarquias, como o tenentismo na década de 1920, e o surgimento de agremiações de dissidentes oligárquicos, como o Partido Democrático, surgido em 1926 e a Aliança Liberal, organizada a partir do final de 1929 e o início de 1930. O desfecho de tais movimentos de contestação resultou na Revolução de 1930. Entendemos tal evento como um processo de 
"modernização conservadora". O conceito de Barrington Moore Junior (1967) é aplicado ao caso brasileiro para a explicitação de que não houve uma "Revolução" no estilo clássico do termo e sim uma ruptura de estilo conservador. Nossa intenção é verificar de que maneira a Revolução de 1930 afetou a política paranaense e quais foram as continuidades e rupturas verificáveis nos levantamentos biográficos desses agentes políticos. Tais levantamentos abrangerão informações como o local e ano de nascimento, a formação, a atuação, os capitais econômicos, os principais cargos políticos ocupados e as conexões familiares e sociais desses agentes no campo político paranaense. A principal perspectiva teórica desse trabalho será a de Pierre Bourdieu nas suas considerações sobre o campo político e os capitais acumulados pelos seus agentes, que incluem, além dos capitais propriamente políticos, os capitais familiares, sociais, econômicos e intelectuais, que acumulam e incrementam suas posições na sociedade paranaense.

Em linhas gerais, a perspectiva teórica de Pierre Bourdieu indica que cada campo é um microcosmo, uma parcela do mundo social (ou macrocosmo) relativamente autônomo em relação à totalidade do mundo social (BOURDIEU, 2011, p.195). Relativa autonomia, pois “os campos não são espaços com fronteiras estritamente delimitadas, totalmente autônomos" (BONNEWITZ, 2003, p.62). Assim, os campos podem se entrecruzar-se, e a inserção de cada agente analisado em diferentes campos proporciona a acumulação de capitais que são decisivos para a noção da posição que tal agente vai ocupar no mundo social. No caso da análise dos agentes do poder legislativo paranaense, os mesmos estão imersos no campo político, e possuem posições de prestígio correspondentes ao acúmulo de capitais políticos. Ressalta-se que o campo político possui relativa autonomia em relação aos demais, ao mesmo tempo em que também é influenciado pelos diversos campos do espaço social, tais como o econômico, o cultural, o acadêmico, entre outros. Os agentes que estão inseridos no campo político, além de serem detentores de capitais propriamente políticos, também possuem capitais vinculados a outros campos da vida social, ocupando posições nos outros campos em que estão concomitantemente inseridos, tais como o econômico, o cultural e o acadêmico. Os "campos" que permeiam a vida social, são compostos de agentes com capitais desiguais que reproduzem o sistema de dominação.

Verificaremos, através da análise de capitais e posições dos agentes do legislativo paranaense, os impactos que a Revolução de 1930 provocou nas suas trajetórias políticas, através do levantamento de capitais sociais, familiares, econômicos, culturais, políticos e 
Revista NEP - Núcleo de Estudos Paranaenses, Curitiba, v.5, n.1, jun. 2019

intelectuais destes agentes, proporcionando também indicações de comparações entre os perfis dos grupos eleitos antes de depois da Revolução de 1930.

\section{Comparação entre os perfis sociais dos deputados federais eleitos antes e depois da}

\section{Revolução de 1930}

Nessa seção, apresentaremos as informações genealógicas dos agentes políticos que vivenciaram a Revolução de 1930. Tais informações indicam a longa presença de famílias tradicionais na classe econômica e politicamente dominante no Paraná. Ricardo Costa de Oliveira (2000) aponta que aproximadamente 50 famílias históricas do período colonial perpetuam sua dominação ao longo dos séculos, em detrimento das transformações políticas e modernização no capitalismo. Nesse sentido, a classe dominante é formada "a partir de um reduzido conjunto de famílias, bastante aparentadas entre si e compartilhando inúmeros ascendentes em comum" (OLIVEIRA, 2000, p.5). Para a validação empírica destes argumentos, Oliveira remete-se à obra "Genealogia Paranaense", de Francisco Negrão, que separa por volumes os descendentes dos primeiros povoadores do Paraná Tradicional a partir de títulos genealógicos, localizando as famílias e as alianças matrimoniais. O volume I corresponde aos descendentes de Baltazar Carrasco dos Reis, o volume II corresponde aos descendentes de João Rodrigues Seixas, o volume III corresponde aos descendentes de João Rodrigues de França. A partir do volume IV, são variados títulos genealógicos ${ }^{3}$. A respeito do significado dos títulos genealógicos, Oliveira assinala que:

\footnotetext{
"O título é o retrato da evolução de uma rede de parentesco, a partir da família do titular, em um efeito progressivo, em cascata. Todos os personagens de um título têm vínculos de parentesco, ou ancestrais em comum, por mais distantes e remotos que sejam. (...) A partir dos quatro grandes troncos familiares que constituem o cerne da classe dominante no Paraná, com uma estruturação política de quase trezentos anos de organização familiar reconhecida, podemos compor unidades familiares menores, pertencendo isoladamente a um ou a vários troncos centrais" (OLIVEIRA, 2000, p.214).
}

\footnotetext{
3 Volume IV: Títulos Laras, Moraes Cordeiro, Mateus Leme, Teixeira de Azevedo, Xavier Pinto, Teixeira Coelho, Pereira Braga e Oliveira Cardoso. Volume V: Títulos Corrêa de Bittencourt, Cardoso de Lima, Taques, Oliveira Vianna, Goés Siqueira, Alves, Marques da Cunha e Azevedo da Silveira. Volume VI: Títulos Macedo, Laynes, Morocine Borba, Martins Lopes, Brandão de Proença, Simas, Souza Pinto, Rodrigues Vianna, Gonçalves Marques, Marques de Jesus, Silva Pereira, Santos, Nascimento de Farias, Maravalhas, Pereiras, Mendonça, Pereira Branco, Freitas de Saldanha, Alvares de Araújo, Soares da Costa, Xavier da Silva, Falcão Bastos, Moreira da Rocha, Gonçalves dos Santos, Pletz, Muller, Kalckman e Bley (OLIVEIRA, 2000; NEGRÃO, 1926; 1927; 1928; 1929; 1946; 1950).
} 
O quadro a seguir traz as informações de local e ano de nascimento, bem como os capitais familiares e os títulos genealógicos dos deputados federais que tiveram seus mandatos atravessados pela Revolução de 1930 no Paraná.

QUADRO 1- Deputados federais com mandato em 1930: informações genealógicas

\begin{tabular}{|l|l|l|}
\hline Nome & Local de nascimento/ano & $\begin{array}{l}\text { Capitais Familiares/ } \\
\text { Títulos Genealógicos }\end{array}$ \\
\hline Plínio Gonçalves Marques & Antonina (PR), 1893 & $\begin{array}{l}\text { Gonçalves Marques } \\
\text { (nascimento, Vol.VI) } \\
\text { Rodrigues Seixas } \\
\text { (matrimônio, Vol.II) }\end{array}$ \\
\hline Arthur Martins Franco & Campo Largo (PR), 1876 & $\begin{array}{l}\text { Xavier Pinto (nascimento, } \\
\text { Vol.IV); Seixas } \\
\text { Rodrigues Seixas } \\
\text { (matrimônio, vol. II) }\end{array}$ \\
\hline João Cid Moreira Garcês & Curitiba (PR), 1885 & $\begin{array}{l}\text { Rodrigues } \\
\text { (matrimônio, vol. II) } \\
\text { Cardoso de Lima } \\
\text { (nascimento, vol.V) }\end{array}$ \\
\hline Eurides Cunha & Campo Largo (PR), 1872 & $\begin{array}{l}\text { Família com chefes } \\
\text { políticos municipais }\end{array}$ \\
\hline
\end{tabular}

Fontes: NEGRÃO; OLIVEIRA, 2000, 1997; NICOLAS, 1977; DHBB CPDOC FGV.

O perfil dos 4 deputados federais com mandatos atravessados pela Revolução de 1930 indica o pertencimento de longa data à classe dominante tradicional, sendo três deles portadores de títulos genealógicos, sendo eles Plínio Marques, Arthur Franco e Moreira Garcês. Por sua vez, Eurides Cunha era ligado a laços de parentesco com chefes políticos locais. Os três portadores de títulos genealógicos por nascimento também incrementaram seus capitais sociais e familiares através de matrimônios com mulheres pertencentes a famílias tradicionais, também portadoras de títulos genealógicos, o que potencializa as relações entre famílias e aumenta as possibilidades de poder e atuação na sociedade paranaense. Todos os deputados federais também nasceram na região categorizada como "Paraná Tradicional", região de antiga ocupação territorial.

Para complementar as informações genealógicas e suas relações com a classe dominante, o próximo quadro apresenta os capitais econômicos dos deputados federais com mandato no Paraná durante a Revolução de 1930. 
Revista NEP - Núcleo de Estudos Paranaenses, Curitiba, v.5, n.1, jun. 2019

QUADRO 2- Deputados federais com mandato em 1930: capitais econômicos

\begin{tabular}{|l|l|}
\hline Nome & Capitais econômicos/sociais \\
\hline Plínio Gonçalves Marques & Grande comércio no Litoral \\
\hline Arthur Martins Franco & Propriedade de terras nos Campos Gerais \\
\hline João Cid Moreira Garcês & Grande comércio em Curitiba \\
\hline Eurides Cunha & $\begin{array}{l}\text { Propriedade de terras e pecuária em Curitiba e Campo } \\
\text { Largo }\end{array}$ \\
\hline
\end{tabular}

Fontes: NEGRÃO; OLIVEIRA, 2000, 1997; NICOLAS, 1977; DHBB CPDOC FGV.

Através das informações deste quadro, constatamos que os quatro deputados federais pertenciam a classe economicamente dominante, sendo as suas propriedades ligadas ao comércio e a agricultura na região do Paraná Tradicional. A dominação contemplava os campos político, econômico e social, em uma lógica de reprodução dos privilégios e da estrutura de classes, no momento de transição da monarquia para a república e de transformações sócio-econômicas.

Em linhas gerais, o perfil dos deputados federais que se elegeram antes da Revolução de 1930 e que tiveram os mandatos atravessados por este evento histórico indica que a totalidade de seus membros eram nascidos no Paraná e pertenciam à classe dominante tradicional local, acumulando capitais sociais, familiares, políticos e econômicos com reprodução de longa duração.

Nesse momento, assinalaremos qual é o perfil genealógico dos deputados federais eleitos após a Revolução de 1930. Buscaremos comparar os perfis dos grupos de deputados federais que vivenciaram o processo político e histórico de tal evento.

QUADRO 3- Deputados federais eleitos após a Revolução de 1930: informações genealógicas

\begin{tabular}{|l|l|l|}
\hline Nome & Local de nascimento/ano & $\begin{array}{l}\text { Capitais Familiares/ } \\
\text { Títulos Genealógicos }\end{array}$ \\
\hline Idálio Sardenberg & Porto Alegre (RS), 1906 & Família Militar \\
\hline Manoel Lacerda Pinto & Lapa (PR), 1893 França & $\begin{array}{l}\text { Rodrigues de } \\
\text { (nascimento, Vol.III) }\end{array}$ \\
\hline $\begin{array}{l}\text { Antônio Jorge Machado da } \\
\text { Silva Lima }\end{array}$ & Ponta Grossa (PR), 1886 & $\begin{array}{l}\text { Carrasco dos Reis } \\
\text { (nascimento, Vol.I) }\end{array}$ \\
\hline Plínio Tourinho & Curitiba (PR), 1882 & $\begin{array}{l}\text { Alves } \\
\text { Vol.V) }\end{array}$ \\
\hline Francisco de Paula Soares & Rio Grande (RS), 1901 & Família Militar \\
\hline Lauro Sodré Lopes & Curitiba (PR), 1898 & \\
\hline Octávio da Silveira & Tupanciretã (RS), 1895 & $\begin{array}{l}\text { Rodrigues Seixas } \\
\text { (Matrimônio, Vol.II) }\end{array}$ \\
\hline Airton Plaisant & Curitiba (PR), 1890 \\
\hline
\end{tabular}


Revista NEP - Núcleo de Estudos Paranaenses, Curitiba, v.5, n.1, jun. 2019

\begin{tabular}{|l|l|l|}
\hline Francisco Ferreira Pereira & Curitiba (PR), 1899 & $\begin{array}{l}\text { Pereiras (nascimento, } \\
\text { Vol. VI) }\end{array}$ \\
\hline Arthur Ferreira dos Santos & Curitiba (PR), 1894 & $\begin{array}{l}\text { Xavier Pinto (nascimento, } \\
\text { Vol.IV) }\end{array}$ \\
\hline
\end{tabular}

Fontes: NEGRÃO; OLIVEIRA, 2000, 1977; NICOLAS, 1977; DHBB CPDOC FGV.

Os dez deputados federais eleitos após a Revolução de 1930 correspondem aos eleitos para a Assembleia Nacional Constituinte e aos eleitos pelo pleito de 1934, que assumiram suas cadeiras em 1935 e tiveram mandato até novembro de 1937, na ocasião do golpe do Estado Novo. Os quatro primeiros deputados citados (Idálio Sardenberg, Manoel Lacerda Pinto, Antônio Jorge Machado da Silva Lima e Plínio Tourinho) foram eleitos para a Assembleia Nacional Constituinte, em 1933. Os demais foram eleitos em outubro de 1934. Nesse grupo, Plínio Tourinho também se inclui, pois foi reeleito para o cargo na ocasião.

No primeiro grupo, todos pertenciam ao PSD, exceto Plínio Tourinho, membro do Partido Liberal. A mesma tendência se se confirma no segundo grupo, composto pelos deputados federais eleitos em 1934, no qual a sua maioria pertencia ao partido governista, o PSD, excetuando-se os deputados Plínio Tourinho, do PSN (Partido Social Nacionalista) e Arthur Ferreira dos Santos, da URP (União Republicana Paranaense).

Dos dez deputados federais, sete nasceram na região do "Paraná Tradicional" e três nasceram no Rio Grande do Sul. Dos deputados nascidos fora do Paraná, dois eram membros de famílias militares, como é o caso de Idálio Sardemberg e Francisco de Paula Soares, o que assinala a presença dos militares na política paranaense. Dos sete deputados federais nascidos no Paraná, seis eram portadores de títulos genealógicos, o que revela a dominação social e política de longa data, seja através do nascimento ou do matrimônio. Nesse sentido, o padrão de dominação e influência política se manteve após a Revolução de 1930.

O próximo quadro apresentará informações de capitais econômicos destes novos agentes detentores de poder político no contexto pós-1930.

QUADRO 4- Deputados federais eleitos após 1930: capitais econômicos

\begin{tabular}{|l|l|}
\hline Nome & Capitais econômicos/sociais \\
\hline Idálio Sardenberg & Alto funcionalismo militar \\
\hline Manoel Lacerda Pinto & Propriedade de engenhos de erva-mate \\
\hline $\begin{array}{l}\text { Antônio Jorge Machado da } \\
\text { Silva Lima }\end{array}$ & Grande propriedade de terras \\
\hline Plínio Tourinho & Alto funcionalismo público e militar \\
\hline
\end{tabular}


Revista NEP - Núcleo de Estudos Paranaenses, Curitiba, v.5, n.1, jun. 2019

\begin{tabular}{|l|l|}
\hline Francisco de Paula Soares & Alto funcionalismo público \\
\hline Lauro Sodré Lopes & Alto funcionalismo público \\
\hline Octávio da Silveira & Alto profissional liberal e professor universitário \\
\hline Airton Plaisant & Alto funcionalismo público \\
\hline Francisco Ferreira Pereira & $\begin{array}{l}\text { Propriedade de terras ligadas ao comércio e a } \\
\text { industrialização da erva-mate }\end{array}$ \\
\hline Arthur Ferreira dos Santos & $\begin{array}{l}\text { Grande comércio e indústria. Alto funcionalismo } \\
\text { público. }\end{array}$ \\
\hline
\end{tabular}

Fontes: NEGRÃO; OLIVEIRA, 2000, 1997; NICOLAS, 1977; DHBB CPDOC FGV.

$\mathrm{Na}$ análise dos capitais econômicos e sociais dos deputados federais eleitos após a Revolução de 1930, assinalamos a ligação com a grande propriedade de terras, comércio e indústria de quatro deputados. Os outros seis deputados eram membros de famílias que pertenciam ao alto funcionalismo público, civil e militar, além da atuação no campo das profissões liberais. Todos pertenciam às altas rodas da sociedade paranaense, nos campos econômicos e sociais. Poucas mudanças são observadas entre o perfil dos deputados federais que se elegeram antes da Revolução de 1930 em relação aos que se elegeram após 1930. Nesse sentido, a amostra de deputados assinala a continuidade dos padrões de dominação socioeconômica, em detrimento das mudanças políticas próprias do período. Verifica-se inclusive a manutenção da influência da propriedade correspondente ao principal produto da economia paranaense do período pré-1930: a erva-mate.

A próxima seção analisará os perfis sociais dos deputados estaduais eleitos no pleito anterior a Revolução de 1930, comparando-os com os deputados estaduais eleitos após 1930.

\section{Comparação entre os perfis sociais dos deputados estaduais eleitos antes e depois da Revolução de 1930}

Nessa seção, apresentaremos as informações genealógicas dos agentes políticos que vivenciaram a Revolução de 1930. O quadro a seguir traz as informações de local e ano de nascimento, bem como os capitais familiares e os títulos genealógicos dos deputados estaduais que tiveram seus mandatos atravessados pela Revolução de 1930 no Paraná.

QUADRO 5- Deputados estaduais com mandato em 1930: informações genealógicas

\begin{tabular}{|l|l|l|}
\hline Nome & Local de nascimento/ano & $\begin{array}{l}\text { Capitais } \\
\text { Títulos Genealógicos }\end{array}$ \\
\hline
\end{tabular}


Revista NEP - Núcleo de Estudos Paranaenses, Curitiba, v.5, n.1, jun. 2019

\begin{tabular}{|c|c|c|}
\hline $\begin{array}{l}\text { Caio Gracho Machado de } \\
\text { Lima }\end{array}$ & Ponta Grossa (PR), 1885 & $\begin{array}{ll}\text { Carrasco dos } & \text { Reis } \\
\text { (nascimento, Vol.I) } & \end{array}$ \\
\hline $\begin{array}{l}\text { Dídio Iratym Affonso da } \\
\text { Costa }\end{array}$ & Guarapuava (PR), 1881 & $\begin{array}{l}\text { Müller } \quad \text { (nascimento, } \\
\text { vol.VI) }\end{array}$ \\
\hline Domingos de Freitas & Palmeira (PR), 1879 & $\begin{array}{l}\text { Família com chefes } \\
\text { políticos municipais }\end{array}$ \\
\hline Edmundo Mercer & Tibagi (PR), 1878 & $\begin{array}{l}\text { Mercer } \quad \text { (nascimento, } \\
\text { vol.VI) }\end{array}$ \\
\hline Elbe Lauro Pospissil & Curitiba (PR), 1893 & \\
\hline Enéas Marques dos Santos & Curitiba (PR), 1883 & $\begin{array}{l}\text { Rodrigues Seixas } \\
\text { (nascimento, Vol.II) }\end{array}$ \\
\hline Ermelino Beckert & Rio Negro (PR), 1873 & \\
\hline $\begin{array}{l}\text { Ermelino Agostinho } \mathrm{de} \\
\text { Leão }\end{array}$ & Curitiba (PR), 1870 & $\begin{array}{l}\text { Rodrigues de França } \\
\text { (nascimento, Vol.III) }\end{array}$ \\
\hline $\begin{array}{ll}\text { Estevam Ribeiro } & \text { do } \\
\text { Nascimento Júnior } & \end{array}$ & Curitiba (PR), 1891 & $\begin{array}{l}\text { Rodrigues de França } \\
\text { (nascimento, Vol.III) }\end{array}$ \\
\hline Francisco Fido Fontana & Curitiba (PR), 1883 & $\begin{array}{l}\text { Rodrigues Seixas } \\
\text { (nascimento, Vol.II) }\end{array}$ \\
\hline $\begin{array}{lll}\text { Francisco Ribeiro } & \text { de } \\
\text { Azevedo Macedo } & \end{array}$ & Campo Largo (PR), 1872 & $\begin{array}{l}\text { Rodrigues Seixas } \\
\text { (nascimento, Vol.II) }\end{array}$ \\
\hline $\begin{array}{l}\text { Genaro Régis Pereira da } \\
\text { Costa }\end{array}$ & Paranaguá (PR), 1901 & $\begin{array}{l}\text { Pereiras (nascimento, } \\
\text { Vol.VI) }\end{array}$ \\
\hline Hernani Nogueira Zaina & & $\begin{array}{ll}\text { Carrasco dos Reis } \\
\text { (matrimônio, Vol.I) }\end{array}$ \\
\hline $\begin{array}{lll}\text { Hildebrando } & \text { Cézar } & \text { de } \\
\text { Souza Araujo } & & \end{array}$ & Imbituva (PR), 1885 & $\begin{array}{l}\text { Alves (nascimento, } \\
\text { Vol.V) } \\
\text { Macedo (matrimônio, vol. } \\
\text { VI) }\end{array}$ \\
\hline João Antônio Xavier & Paranaguá (PR), 1852 & $\begin{array}{l}\text { Silva Pereira (nascimento, } \\
\text { Vol.VI) }\end{array}$ \\
\hline João Cândido de Oliveira & $\begin{array}{l}\text { Almirante } \\
(\mathrm{PR}), 1865 \\
\end{array}$ & $\begin{array}{l}\text { Família com chefes } \\
\text { políticos municipais }\end{array}$ \\
\hline João Fleury da Rocha & Ouro Preto (MG), 1889 & $\begin{array}{l}\text { Família com deputados na } \\
\text { ALEP }\end{array}$ \\
\hline João Leite de Paula e Silva & Piancó (PB), 1860 & $\begin{array}{l}\text { Góes de Siqueira } \\
\text { (matrimônio, vol. V) }\end{array}$ \\
\hline João Sampaio & Lapa (PR), 1864 & $\begin{array}{l}\text { Família com chefes } \\
\text { políticos locais. }\end{array}$ \\
\hline Leovigildo Barbosa Ferraz & Piracicaba (SP), 1885 & \\
\hline Lysandro Alves de Araujo & Palmeira (PR), 1878 & $\begin{array}{l}\text { Rodrigues de França } \\
\text { (nascimento, Vol.II) }\end{array}$ \\
\hline Manoel de Oliveira Franco & Curitiba (PR), 1894 & $\begin{array}{l}\text { Rodrigues Seixas } \\
\text { (nascimento, Vol.II) }\end{array}$ \\
\hline Romualdo Antônio Baraúna & Santo Amaro (BA), 1872 & $\begin{array}{ll}\text { Carrasco dos Reis } \\
\text { (matrimônio, Vol.I) }\end{array}$ \\
\hline $\begin{array}{l}\text { Sylvano Alves da Rocha } \\
\text { Loures }\end{array}$ & Palmas (PR), 1864 & $\begin{array}{ll}\text { Carrasco dos } & \text { Reis } \\
\text { (nascimento, Vol.I) } & \end{array}$ \\
\hline
\end{tabular}


Revista NEP - Núcleo de Estudos Paranaenses, Curitiba, v.5, n.1, jun. 2019

\begin{tabular}{|l|l|l|}
\hline Tasso da Silveira & Curitiba (PR), 1895 & $\begin{array}{l}\text { Azevedo de Macedo } \\
\text { (nascimento, Vol.V) }\end{array}$ \\
\hline Theóphilo Soares Gomes & Antonina (PR), 1894 & $\begin{array}{l}\text { Título Rodrigues França } \\
\text { (matrimônio, Vol.III) }\end{array}$ \\
\hline Vespasiano de Mello & Jaguariaíva (PR), 1886 & $\begin{array}{l}\text { Família com chefes } \\
\text { políticos municipais }\end{array}$ \\
\hline Wallace de Mello. & Laranjeiras (SE), 1872. & $\begin{array}{l}\text { Família com chefes } \\
\text { políticos municipais. }\end{array}$ \\
\hline
\end{tabular}

Fontes: NEGRÃO; OLIVEIRA, 2000, 1997; NICOLAS, 1984; ALEP.

Dos 28 deputados estaduais com mandato na Assembleia Legislativa na ocasião da Revolução de 1930, 22 nasceram no Paraná (não foi possível localizar o local de nascimento do deputado Hernani Nogueira Zaina). Todos eles nasceram na região do Paraná Tradicional, de antiga ocupação. Destes 22 deputados paranaenses, 16 eram portadores de títulos genealógicos, seja através do nascimento ou do matrimônio, o que indica a longa duração da dominação e reprodução dos poderes políticos e sociais. Por sua vez, 5 deputados estaduais nascidos no Paraná tinham ligações de parentesco com chefes políticos dos seus municípios, desenvolvendo redes de contatos políticos coronelísticos. O único deputado paranaense que não possuía laços de parentesco com a elite política local era Elbe Lauro Pospissil, neto de Antônio Pospissil, imigrante alemão estabelecido no Brasil a partir de 1862, pioneiros da militância política operária no estado (TOURINHO, 1990)

Cinco deles nasceram fora do Paraná. Destes deputados, dois contraíram ligações familiares com a classe dominante local através do casamento e dois desenvolveram relações familiares que reproduziram poderes políticos nos municípios e no interior da Assembleia Legislativa. Desse modo, os "outsiders" se incorporaram a sociedade local e garantiram suas influências e possibilidades de ação.

O próximo quadro trata dos capitais econômicos dos deputados estaduais que tiveram seus mandatos atravessados pela Revolução de 1930.

QUADRO 6- Deputados estaduais com mandato em 1930: capitais econômicos

\begin{tabular}{|l|l|}
\hline Nome & Capitais econômicos/sociais \\
\hline $\begin{array}{l}\text { Caio Gracho Machado de } \\
\text { Lima }\end{array}$ & Grande propriedade de terras. \\
\hline $\begin{array}{l}\text { Dídio Iratym Affonso da } \\
\text { Costa }\end{array}$ & Alto funcionalismo militar. \\
\hline Domingos de Freitas & $\begin{array}{l}\text { Propriedade de terras ligadas ao comércio, } \\
\text { industrialização e exportação da erva-mate. }\end{array}$ \\
\hline
\end{tabular}




\begin{tabular}{|c|c|}
\hline Edmundo Mercer & Propriedade de gado e terras na região de Castro (PR). \\
\hline Elbe Lauro Pospissil & Alto funcionalismo público. \\
\hline Enéas Marques dos Santos & Alto funcionalismo público. \\
\hline Ermelino Beckert & Alto funcionalismo público. \\
\hline $\begin{array}{l}\text { Ermelino Agostinho de } \\
\text { Leão }\end{array}$ & $\begin{array}{l}\text { Propriedade de terras ligadas ao comércio e a indústria. } \\
\text { Alto funcionalismo público. }\end{array}$ \\
\hline $\begin{array}{l}\text { Estevam Ribeiro do } \\
\text { Nascimento Júnior }\end{array}$ & $\begin{array}{l}\text { Propriedade de terras ligadas ao comércio e a indústria } \\
\text { de erva-mate na região de Clevelândia. }\end{array}$ \\
\hline Francisco Fido Fontana & $\begin{array}{l}\text { Propriedade de terras ligadas ao comércio e a indústria } \\
\text { de erva-mate, com desenvolvimento de maquinário. }\end{array}$ \\
\hline $\begin{array}{l}\text { Francisco Ribeiro de } \\
\text { Azevedo Macedo }\end{array}$ & $\begin{array}{l}\text { Propriedade de terras ligadas ao comércio, } \\
\text { industrialização e exportação da erva-mate. Propriedade } \\
\text { de fontes de água mineral. }\end{array}$ \\
\hline $\begin{array}{l}\text { Genaro Régis Pereira da } \\
\text { Costa }\end{array}$ & Alto funcionalismo público. \\
\hline Hernani Nogueira Zaina & $\begin{array}{l}\text { Propriedade de terras ligadas ao comércio e a indústria } \\
\text { de erva-mate. }\end{array}$ \\
\hline $\begin{array}{lll}\text { Hildebrando } & \text { Cézar } & \text { de } \\
\text { Souza Araujo } & & \end{array}$ & $\begin{array}{l}\text { Propriedade de terras ligadas ao comércio e a indústria } \\
\text { de erva-mate. }\end{array}$ \\
\hline João Antônio Xavier & $\begin{array}{l}\text { Grande propriedade de terras e indústrias no Litoral. } \\
\text { Alto funcionalismo público. }\end{array}$ \\
\hline João Cândido de Oliveira & Grande propriedade comercial. \\
\hline João Fleury da Rocha & Alto funcionalismo público. \\
\hline João Leite de Paula e Silva & $\begin{array}{l}\text { Grande propriedade de terras. Alto funcionalismo } \\
\text { público. }\end{array}$ \\
\hline João Sampaio & $\begin{array}{l}\text { Propriedade de terras ligadas ao comércio e produção de } \\
\text { café. }\end{array}$ \\
\hline Leovigildo Barbosa Ferraz & $\begin{array}{l}\text { Propriedade de terras ligadas ao comércio, produção e } \\
\text { exportação de café. }\end{array}$ \\
\hline Lysandro Alves de Araújo & Grande propriedade industrial e comercial. \\
\hline Manoel de Oliveira Franco & $\begin{array}{l}\text { Grande propriedade de terras. Alto funcionário público } \\
\text { e professor universitário. }\end{array}$ \\
\hline Romualdo Antônio Baraúna & $\begin{array}{l}\text { Grande propriedades de terras. Alto funcionalismo } \\
\text { público. }\end{array}$ \\
\hline $\begin{array}{l}\text { Sylvano Alves da Rocha } \\
\text { Loures }\end{array}$ & $\begin{array}{l}\text { Grande propriedade de terras. Alto funcionário público } \\
\text { e professor universitário. }\end{array}$ \\
\hline Tasso da Silveira & Família intelectual, com escritores renomados. \\
\hline Theóphilo Soares Gomes & $\begin{array}{l}\text { Propriedade de terras ligadas ao } \\
\text { industrialização e exportação da erva-mate. }\end{array}$ \\
\hline Vespasiano de Mello & Comércio em Castro. \\
\hline Wallace de Mello & alismo público. \\
\hline
\end{tabular}

Fontes: NEGRÃO; OLIVEIRA, 2000, 1997; NICOLAS, 1984; ALEP.

$\mathrm{Na}$ análise dos capitais econômicos e sociais dos 28 deputados estaduais com mandatos na ocasião da Revolução de 1930, assinalamos que 17 deles eram detentores de propriedades de terras ligadas à agricultura, ao comércio, à criação de gado e à indústria. 
Identificamos dois dos precursores da propriedade cafeeira, Leovigildo Barbosa Ferraz e João Sampaio, bem como grandes comerciantes, industriais e importadores de erva-mate, o principal produto da economia do período, com destaque aos nomes de Domingos de Freitas, Estevam Ribeiro do Nascimento Júnior, Francisco Fontana, Francisco Ribeiro de Macedo, Hernani Zaina, Hildebrando de Araújo, Theóphilo Gomes, entre outros, associados a famílias ervateiras do Paraná Tradicional, especialmente ao Litoral. Os outros deputados estaduais eram ligados aos altos postos da sociedade paranaense através de profissões ligadas ao funcionalismo militar (Dídio Affonso da Costa) e público (Elbe Lauro Pospissil, Enéas Marques dos Santos, Ermelino Beckert, Genaro Régis Pereira da Costa, João Fleury da Rocha e Wallace de Mello). Também destacam-se os deputados estaduais com atuação no grande comércio e indústria (João Cândido de Oliveira, Lysandro Alves de Araújo e Vespasiano de Mello). Apenas Tasso Silveira não possui uma forte ligação com as classes proprietárias ou pertencentes à elite do funcionalismo público. No entanto, ele pertence a uma família intelectual com escritores renomados. Trata-se de uma grande rede de capitais políticos e econômicos reproduzidos através de relações e laços de parentesco em um grau relativamente homogêneo de organização da classe dominante paranaense.

Todos os deputados federais e estaduais pertenciam ao Partido Republicano Paranaense. Na passagem do Império para a República, o processo foi conduzido pelos mesmos agentes políticos, detentores de privilégios, poder e propriedade, associados ao grupo militar em ascensão no início da República (SOUZA, 2001, p.166). Verificamos um momento de modernização conservadora na política brasileira que se reflete em âmbito local. Estruturava-se um sistema político oligárquico e liberal contraditório, que no discurso proclamava a ampliação da representação de novos setores sociais e, em contrapartida, praticava a exclusão destes mesmos grupos na arena política para o favorecimento e a reprodução do sistema monocultor, agrário e latifundiário predominante (SOUZA, 2001, p.169). O sistema político transferiu o foco do poder para os estados, dominados por oligarcas que controlavam os coronéis municipais, "condutores da massa eleitoral incapacitada e impotente para participar do processo político que lhes fora aberto com o regime representativo imposto pela Constituição de 1891" (SOUZA, 2001, p.185).

No Paraná, tal lógica se reproduziu desde o início da República, com a criação de duas legendas: o Partido Republicano Liberal, liderado por Vicente Machado e composto por antigos membros do Partido Conservador do Império, e a União Republicana, chefiada 
por Generoso Marques, agremiação composta antigos liberais e conservadores do Império que não obtiveram espaço político suficiente de atuação na legenda de Vicente Machado. Esses dois grupos políticos resolveram suas diferenças em 1908 com a Coligação Republicana, a responsável em uni-los em uma só legenda: o Parido Republicano Paranaense. Assim, toda tentativa de oposição era combatida para garantir a hegemonia do Partido Republicano, condição que permaneceu a mesma até a Revolução de 1930 (GOULART, 2004; DAGOSTIM, 2011).

Focos de resistência e questionamento a tal ordenamento político começaram a se intensificar na década de 1920, com novos movimentos de insurgência, como o tenentismo, e novas agremiações partidárias, como o Partido Democrático. Esse é o contexto no qual este conjunto de deputados federais e estaduais estão inseridos. No entanto, na análise da composição social deste conjunto de agentes do período pré-1930, verificamos que apenas um deputado (Elbe Pospissil, ligado a lutas operárias) era representante de um estrato social que diferia do hegemônico. Verificamos que a dinâmica política do período pré-1930 impede a ascensão de qualquer grupo contra- hegemônico. Para exemplificar tal afirmação, assinalamos o caso do candidato do Partido Democrático Paranaense a deputado federal, David Carneiro, que se desgastou política e pessoalmente com o não reconhecimento de sua candidatura, a despeito de seu prestígio e popularidade local, em especial com a classe empresarial.

Os próximos quadros informarão quais são os perfis sociais e familiares dos deputados estaduais eleitos após a Revolução de 1930, verificando quais as novidades que o novo processo fomentou na política paranaense. Eles estarão divididos por partidos políticos. O primeiro e maior deles é o PSD, partido de sustentação do interventor Manoel Ribas e situacionista. O segundo partido é a União Republicana Paranaense, agremiação composta de chefes políticos remanescentes do período pré-1930, atuando em oposição ao interventor Manoel Ribas e ao PSD. O terceiro é o Partido Social Nacionalista, integrado por agentes atuantes na Revolução de 1930 que passaram a exercer a oposição as políticas e aos atos posteriores à Revolução.

QUADRO 7- Deputados estaduais do PSD eleitos após a Revolução de 1930: informações genealógicas

\begin{tabular}{|l|l|l|}
\hline Nome & Local de nascimento/ano & $\begin{array}{l}\text { Capitais Familiares/ } \\
\text { Títulos Genealógicos }\end{array}$ \\
\hline
\end{tabular}


Revista NEP - Núcleo de Estudos Paranaenses, Curitiba, v.5, n.1, jun. 2019

\begin{tabular}{|c|c|c|}
\hline $\begin{array}{l}\text { Antônio Augusto de } \\
\text { Carvalho Chaves }\end{array}$ & Macaíba (RN), 1875 & $\begin{array}{l}\text { Rodrigues de Seixas } \\
\text { (nascimento, Vol.II) }\end{array}$ \\
\hline Acyr Guimarães & Curitiba (PR), 1896 & $\begin{array}{l}\text { Rodrigues Seixas } \\
\text { (nascimento, Vol.II) }\end{array}$ \\
\hline Adalberto Scherer & Palmeira (PR), 1893 & $\begin{array}{l}\text { Macedo (matrimônio, } \\
\text { Vol.VI) }\end{array}$ \\
\hline $\begin{array}{l}\text { Agostinho Pereira Alves } \\
\text { Filho }\end{array}$ & Paranaguá (PR), 1903 & $\begin{array}{l}\text { Pereiras } \quad \text { (nascimento, } \\
\text { Vol.VI) }\end{array}$ \\
\hline Alceu Ferreira & Lapa (PR), 1889 & $\begin{array}{ll}\begin{array}{l}\text { Carrasco dos } \\
\text { (nascimento, Vol.I) }\end{array} & \text { Reis } \\
\end{array}$ \\
\hline Augusto Santos & (BA), 1874 & \\
\hline Brasil Pinheiro Machado & Ponta Grossa (PR), 1907 & $\begin{array}{l}\text { Cardoso de Lima } \\
\text { (nascimento, Vol.V) }\end{array}$ \\
\hline $\begin{array}{l}\text { Caio Gracho Machado de } \\
\text { Lima }\end{array}$ & Ponta Grossa (PR), 1885 & $\begin{array}{ll}\begin{array}{l}\text { Carrasco dos } \\
\text { (nascimento, }\end{array} \text { Vol.I) } & \text { Reis } \\
\end{array}$ \\
\hline Camilo Stellfeld & Curitiba (PR), 1902 & $\begin{array}{l}\text { Kalckmann (nascimento, } \\
\text { Vol.VI) }\end{array}$ \\
\hline Djalma Rocha Al-Chueyr & São Paulo (SP), 1904 & Família Militar \\
\hline Elbe Lauro Pospissil & Curitiba (PR), 1893 & \\
\hline Erasto Gaertner & Curitiba (PR), 1900 & Família religiosa \\
\hline Frederico Faria de Oliveira & Lapa (PR), 1893 & $\begin{array}{l}\text { Nascimento de Farias } \\
\text { (nascimento, Vol.VI) }\end{array}$ \\
\hline Helvídio da Silva Pereira & Curitiba (PR), 1883 & $\begin{array}{l}\text { Rodrigues Seixas } \\
\text { (nascimento, Vol.II) }\end{array}$ \\
\hline $\begin{array}{lll}\text { João } & \text { Theophilo } & \text { Gomy } \\
\text { Júnior } & & \\
\end{array}$ & Curitiba (PR), 1887 & $\begin{array}{l}\text { Rodrigues de Seixas } \\
\text { (matrimônio, Vol.II) }\end{array}$ \\
\hline $\begin{array}{l}\text { José Manoel Ribeiro dos } \\
\text { Santos }\end{array}$ & Sete Lagoas (MG), 1894 & \\
\hline Linneu Madureira Novais & Castro (PR), 1908 & $\begin{array}{ll}\begin{array}{l}\text { Carrasco dos } \\
\text { (nascimento, Vol.I) }\end{array} & \text { Reis } \\
\end{array}$ \\
\hline Mário Erichsen & Curitiba (PR), 1892 & $\begin{array}{l}\begin{array}{l}\text { Rodrigues de França } \\
\text { (nascimento, Vol.III) }\end{array} \\
\text { (nas }\end{array}$ \\
\hline Nelson José Corrêa & Rio Negro (PR), 1902 & $\begin{array}{l}\text { Teixeira de Coelho } \\
\text { (nascimento, Vol.IV) }\end{array}$ \\
\hline $\begin{array}{l}\text { Oscar Borges de Macedo } \\
\text { Ribas }\end{array}$ & Palmeira (PR), 1894 & $\begin{array}{l}\text { Rodrigues Seixas } \\
\text { (nascimento, Vol.II) }\end{array}$ \\
\hline $\begin{array}{l}\text { Ovande Ferreira do Amaral } \\
\text { e Silva }\end{array}$ & Rio Negro (PR), 1900 & $\begin{array}{ll}\begin{array}{l}\text { Carrasco dos } \\
\text { (nascimento, Vol.I) }\end{array} & \text { Reis } \\
\end{array}$ \\
\hline Raul Gomes Pereira & Curitiba (PR), 1903 & \\
\hline Alfredo Venske & & \\
\hline
\end{tabular}

Fontes: NEGRÃO; OLIVEIRA, 2000, 1997; NICOLAS, 1984; ALEP.

O primeiro grupo analisado corresponde aos membros do PSD, partido fundado pelo interventor Manoel Ribas, que oferece as bases de apoio ao governo Vargas. Ele corresponde a maioria na Assembleia Legislativa, somando 23 deputados. Na observação do perfil social 
e genealógico de deputados, destacamos que 18 deles são nascidos na região do Paraná Tradicional. Destes 18 deputados, 14 são portadores de títulos genealógicos adquiridos através do nascimento ou do matrimônio, o que revela o pertencimento aos grupos que dominam os campos da política, da sociedade e da economia paranaense ao longo dos séculos. Não houve, portanto, ruptura com os antigos padrões de dominação verificados no período anterior a revolução de 1930 e nem aos séculos da história política passada.

Dos 4 deputados nascidos fora do Paraná, um era portador do título Rodrigues Seixas, e um era de família militar. Não obtivemos informações biográficas de Augusto Santos e José Manuel Ribeiro dos Santos. Outro deputado sem maiores informações quanto a família e local de nascimento é Alfredo Venske.

O próximo quadro tratará dos capitais econômicos dos deputados estaduais do PSD eleitos após a Revolução de 1930.

QUADRO 8- Deputados estaduais do PSD: capitais econômicos

\begin{tabular}{|c|c|}
\hline Nome & Capitais econômicos/sociais \\
\hline $\begin{array}{l}\text { Antônio Augusto de } \\
\text { Carvalho Chaves }\end{array}$ & Alto funcionalismo público. \\
\hline Acyr Guimarães & $\begin{array}{l}\text { Grande propriedade de terras. Alto funcionalismo } \\
\text { público. }\end{array}$ \\
\hline Adalberto Scherer & $\begin{array}{l}\text { Propriedade de terras ligadas ao comércio e a } \\
\text { industrialização de erva-mate e madeira. }\end{array}$ \\
\hline $\begin{array}{l}\text { Agostinho Pereira Alves } \\
\text { Filho }\end{array}$ & Alto funcionalismo militar. \\
\hline Alceu Ferreira & $\begin{array}{l}\text { Grande propriedade de terras (Lapa, PR). Alto } \\
\text { profissional liberal e professor universitário. }\end{array}$ \\
\hline Augusto Santos & Comércio em Tibagi (PR) \\
\hline Brasil Pinheiro Machado & Alto funcionalismo público. Professor universitário. \\
\hline $\begin{array}{l}\text { Caio Gracho Machado de } \\
\text { Lima }\end{array}$ & Grande propriedade de terras. \\
\hline Camilo Stellfeld & Grande comércio farmacêutico. \\
\hline Djalma Rocha Al-Chueyr & Alto funcionalismo militar. \\
\hline Elbe Lauro Pospissil & Alto funcionário público \\
\hline Erasto Gaertner & Alto profissional liberal e professor universitário \\
\hline Frederico Faria de Oliveira & Comércio (Lapa, PR). \\
\hline Helvídio da Silva Pereira & Alto profissional liberal e funcionário público. \\
\hline $\begin{array}{l}\text { João Theophilo Gomy } \\
\text { Júnior }\end{array}$ & Alto profissional liberal e funcionário público. \\
\hline
\end{tabular}


Revista NEP - Núcleo de Estudos Paranaenses, Curitiba, v.5, n.1, jun. 2019

\begin{tabular}{|l|l|}
\hline $\begin{array}{l}\text { José Manoel Ribeiro dos } \\
\text { Santos }\end{array}$ & Alto profissional liberal. \\
\hline Linneu Madureira Novais & $\begin{array}{l}\text { Alto profissional liberal. Propriedade de terras na região } \\
\text { de Castro, PR. }\end{array}$ \\
\hline Mário Erichsen & Alto profissional liberal. \\
\hline Nelson José Corrêa & Alto profissional liberal e funcionário público. \\
\hline $\begin{array}{l}\text { Oscar Borges de Macedo } \\
\text { Ribas }\end{array}$ & $\begin{array}{l}\text { Grande propriedade de terras. Comércio de madeira } \\
\text { (Castro, PR) }\end{array}$ \\
\hline $\begin{array}{l}\text { Ovande Ferreira do Amaral } \\
\text { e Silva }\end{array}$ & Alto profissional liberal e funcionário público. \\
\hline Raul Gomes Pereira & Alto funcionário militar e professor universitário. \\
\hline Alfredo Venske & Industrial. \\
\hline
\end{tabular}

Fontes: NEGRÃO; OLIVEIRA, 2000, 1997; NICOLAS, 1984; ALEP.

Dos 23 deputados do PSD eleitos após a Revolução de 1930, cinco eram proprietários de grandes extensões de terras, o que indica a permanência da influência desta propriedade para o volume de capitais para os seus agentes e suas famílias. Apenas um deles (Adalberto Scherer) tinha propriedade rural vinculada à erva-mate, o que indica um declínio deste setor da economia paranaense, se comparado a outros momentos da história local. Vale destacar também que esse mesmo deputado, Adalberto Scherer, estava também vinculado a um setor em expansão na economia: o madeireiro, setor no qual o deputado Oscar Borges de Macedo Ribas atuava. Visualizamos a modernização da antiga propriedade em novos ramos. A indústria e o comércio também são as propriedades de atuação de outros 4 deputados. A recorrência de altos funcionários públicos, sejam eles civis ou militares, também é visível na composição dos deputados do PSD, às vezes somados a propriedade de terras e meios de produção ou ao acúmulo de capitais intelectuais, como é o caso de professores universitários. Ao todo, são 11 deputados do PSD que se enquadram nestas categorias. Às vezes concomitantes ao funcionalismo público, destacamos a presença de 9 profissionais liberais de notável atuação nos seus municípios, o que garante uma quantidade considerável de capitais para a reprodução social.

O próximo quadro indicará as informações genealógicas dos deputados estaduais da União Republicana Paranaense.

QUADRO 9- Deputados estaduais da URP eleitos após a Revolução de 1930: informações genealógicas

\begin{tabular}{|l|l|l|}
\hline Nome & Local de nascimento/ano & $\begin{array}{l}\text { Capitais } \\
\text { Títulos Genealógicos }\end{array}$ \\
\hline
\end{tabular}


Revista NEP - Núcleo de Estudos Paranaenses, Curitiba, v.5, n.1, jun. 2019

\begin{tabular}{|l|l|l|}
\hline Caetano Munhoz da Rocha & Antonina (PR), 1874 & $\begin{array}{l}\text { Carrasco dos Reis } \\
\text { (nascimento, Vol.I) }\end{array}$ \\
\hline Alcides Pereira Júnior & Paranaguá (PR), 1901 & $\begin{array}{l}\text { Góes de Siqueira } \\
\text { (nascimento, vol.V). }\end{array}$ \\
\hline Carlos Ribeiro de Macedo & Campo Largo (PR), 1893 & $\begin{array}{l}\text { Rodrigues Seixas e } \\
\text { Cardoso } \\
\text { (naveira vamento, vol. II e IV) }\end{array}$ \\
\hline Laertes de Macedo Munhoz & Curitiba (PR), 1900 & $\begin{array}{l}\text { Carrasco dos Reis e } \\
\text { Rodrigues Seixas } \\
\text { (nascimento e } \\
\text { matrimônio, Vol.I e II) }\end{array}$ \\
\hline $\begin{array}{l}\text { Lindolpho Pessoa da Cruz } \\
\text { Marques }\end{array}$ & Bananeiras (PB), 1882 & $\begin{array}{l}\text { Carrasco dos Reis } \\
\text { (matrimônio, vol.I) }\end{array}$ \\
\hline
\end{tabular}

Fontes: NEGRÃO; OLIVEIRA, 2000, 1997; NICOLAS, 1984; ALEP.

$\mathrm{Na}$ análise da composição social dos cinco deputados da União Republicana Paranaense, assinalamos que quatro deles eram nascidos no Paraná, sendo estes quatro deputados membros da classe dominante tradicional e portadores de títulos genealógicos por nascimento. Apenas Lindolpho Pessoa era paraibano, o que não impede, porém, a sua integração com a classe dominante tradicional, sendo ele portador do título genealógico Carrasco dos Reis e possuindo estreitas relações com a classe política e economicamente hegemônica no período pré-1930. O próximo quadro indicará os capitais econômicos destes deputados da URP.

QUADRO 10- Deputados estaduais da URP: capitais econômicos

\begin{tabular}{|l|l|l|}
\hline Nome & Capitais econômicos/sociais & \\
\hline Caetano Munhoz da Rocha & $\begin{array}{l}\text { Propriedade de terras ligadas ao comércio e a } \\
\text { industrialização de erva-mate. }\end{array}$ \\
\hline Alcides Pereira Júnior & Grande comércio. Alto funcionalismo público. & \\
\hline Carlos Ribeiro de Macedo & $\begin{array}{l}\text { Propriedade de terras ligadas ao comércio e a } \\
\text { industrialização da erva-mate e da madeira. Alto } \\
\text { profissional liberal. }\end{array}$ \\
\hline Laertes de Macedo Munhoz & $\begin{array}{l}\text { Propriedade de terras ligadas ao comércio e a } \\
\text { industrialização de erva-mate. }\end{array}$ \\
\hline $\begin{array}{l}\text { Lindolpho Pessoa da Cruz } \\
\text { Marques }\end{array}$ & \begin{tabular}{l} 
Alto profissional liberal e funcionário público. \\
\hline
\end{tabular}
\end{tabular}

Fontes: NEGRÃO; OLIVEIRA, 2000, 1997; NICOLAS, 1984; ALEP.

Os cinco deputados da bancada da URP são membros da classe economicamente dominante, seja através do comércio, das altas profissões liberais ou da grande propriedade de terras. Três deles eram diretamente ligados a propriedade de comércio e industrialização da erva-mate, o principal produto da economia do Paraná entre o final do século XIX e o 
início do século XX. Um deles, Carlos Ribeiro de Macedo, estava vinculado a propriedade em expansão, a relacionada à madeira. O próximo quadro trata das informações genealógicas dos deputados estaduais do Partido Social Nacionalista.

QUADRO 11- Deputados estaduais do PSN eleitos após a Revolução de 1930: informações genealógicas

\begin{tabular}{|l|l|l|}
\hline Nome & Local de nascimento/ano & $\begin{array}{l}\text { Capitais } \\
\text { Títulos Genealógicos }\end{array}$ \\
\hline Antônio Couto Pereira & Baturité (CE), 1896 & $\begin{array}{l}\text { Cardoso de Lima } \\
\text { (matrimônio, vol.V) }\end{array}$ \\
\hline Joaquim Pereira de Macedo & Porto de Cima (PR), 1858 & $\begin{array}{l}\text { Rodrigues Seixas } \\
\text { (nascimento, Vol.II) } \\
\text { Xavier } \\
\text { (matrimônio, vol. IV) }\end{array}$ \\
\hline $\begin{array}{l}\text { Jorge Becher } \\
\text { Manoel de Alencar }\end{array}$ & Buenos Aires (ARG), 1865 & $\begin{array}{l}\text { Rodrigues } \\
\text { (nascimento, Vol.II) }\end{array}$ \\
\hline Guimarães & Curitiba (PR), 1885 & \multicolumn{2}{|c|}{ Seixas } \\
\hline
\end{tabular}

Fontes: NEGRÃO; OLIVEIRA, 2000, 1997; NICOLAS, 1984; ALEP.

Dos cinco deputados da bancada do Partido Social Nacionalista, três eram portadores de títulos genealógicos de longa duração, o que revela a correspondência com a classe dominante tradicional. Dois deles por nascimento e um por matrimônio, como é o caso de Antônio Couto Pereira, cearense casado com uma mulher da classe dominante local. Por sua vez, Jorge Becher possuía grande influência na sua base eleitoral, Ponta Grossa, como comerciante, e Ulysses Falcão Vieira como professor universitário e alto servidor público. O próximo quadro trata dos capitais econômicos dos membros da bancada do PSN.

QUADRO 12- Deputados estaduais do PSN: capitais econômicos

\begin{tabular}{|l|l|}
\hline Nome & Capitais econômicos/sociais \\
\hline Antônio Couto Pereira & Grande comércio em Curitiba \\
\hline Joaquim Pereira de Macedo & $\begin{array}{l}\text { Propriedade de terras ligadas ao comércio e a } \\
\text { industrialização da erva-mate e do trigo. }\end{array}$ \\
\hline Jorge Becher & Grande comércio em Ponta Grossa \\
\hline
\end{tabular}


Revista NEP - Núcleo de Estudos Paranaenses, Curitiba, v.5, n.1, jun. 2019

\begin{tabular}{|l|l|}
\hline $\begin{array}{l}\text { Manoel de Alencar } \\
\text { Guimarães }\end{array}$ & $\begin{array}{l}\text { Grande propriedade de terras. Alto funcionalismo } \\
\text { público. }\end{array}$ \\
\hline Ulysses Falcão Vieira & Alto funcionalismo público. Professor Universitário. \\
\hline
\end{tabular}

Fontes: NEGRÃO; OLIVEIRA, 2000, 1997; NICOLAS, 1984; ALEP.

A partir do quadro, constatamos que os três portadores de títulos genealógicos possuíam grandes propriedades ligadas ao comércio, a agricultura e a indústria da erva-mate. Assinalamos que todos os membros da bancada do PSN tinham altas posições sociais e econômicas, incrementando os seus capitais políticos.

A próxima seção analisará os capitais políticos dos deputados federais que tiveram seus mandatos atravessados pela Revolução de 1930. Compararemos com o perfil dos deputados que foram eleitos após a Revolução de 1930, verificando as mudanças e as permanências que tal processo propiciou a arena política.

Comparação entre os perfis políticos dos deputados federais eleitos antes e depois da Revolução de 1930

Nas seções anteriores, assinalamos as características sociais, econômicas e genealógicas dos deputados federais e estaduais cujos mandatos foram atravessados pelo processo histórico da Revolução de 1930. A partir deste momento, nos deteremos a informações de cunho político, a respeito de cargos, partidos, atuação e liderança destes agentes no contexto de mudanças e permanências observadas pelo processo revolucionário local.

O próximo quadro oferecerá informações quanto aos capitais políticos dos deputados federais correspondentes a eleição anterior à Revolução de 1930, bem como informações quanto a formação destes agentes, muitas vezes associadas a carreira política dos mesmos.

QUADRO 13 - Capitais políticos dos deputados federais com mandato em 1930

\begin{tabular}{|c|c|c|}
\hline Nome & Formação & Cargos Políticos/períodos \\
\hline $\begin{array}{ll}\text { Plínio } & \text { Gonçalves } \\
\text { Marques } & \end{array}$ & Medicina, RJ & $\begin{array}{l}\text { Deputado Estadual, 1916- 1921; Deputado } \\
\text { Federal, 1921-1930. }\end{array}$ \\
\hline $\begin{array}{l}\text { Arthur } \\
\text { Franco }\end{array}$ & $\begin{array}{l}\text { Engenharia } \\
\text { Civil, SP }\end{array}$ & $\begin{array}{l}\text { Secretário de Estado dos Negócios da } \\
\text { Fazenda, 1912 a 1916; Deputado estadual, } \\
\text { 1920-1923; Deputado federal, } 1923 \text { a 1930; }\end{array}$ \\
\hline
\end{tabular}


Revista NEP - Núcleo de Estudos Paranaenses, Curitiba, v.5, n.1, jun. 2019

\begin{tabular}{|l|l|l|}
\hline João Moreira Garcês & $\begin{array}{l}\text { Engenharia } \\
\text { Civil, SP }\end{array}$ & $\begin{array}{l}\text { Diretor de Obras Públicas, 1912-1919; } \\
\text { Secretário de Negócios da Fazenda, } \\
\text { Agricultura Obras Públicas, 1919; } \\
\text { Prefeito de Curitiba, 1920-1928; Deputado } \\
\text { Federal pelo Paraná, 1929-1930; Prefeito de } \\
\text { Curitiba, 1938-1940; }\end{array}$ \\
\hline Eurides Cunha & Direito, SP & $\begin{array}{l}\text { Deputado estadual, 1910-1918; Prefeito de } \\
\text { Jaguariaíva 1912-1920; } \\
\text { Vice-presidente do estado, 1920-1924, } \\
\text { Deputado Federal, 1925-1928; } \\
\text { Prefeito de Curitiba, 1928-1930; Deposto } \\
\text { pela Revolução de 1930. }\end{array}$ \\
\hline
\end{tabular}

Fontes: NEGRÃO; OLIVEIRA, 2000, 1997; NICOLAS, 1977; DHBB CPDOC FGV.

Os quatro deputados federais que tinham mandatos na ocasião da Revolução de 1930 possuíram formações superiores fora do estado do Paraná, dado que a primeira universidade do estado foi fundada em 1912. Dois deles se formaram em Engenharia Civil, um em Direito e um em Medicina, os cursos mais tradicionais e prestigiados da época, reservando um acúmulo de capital intelectual considerável para estes agentes.

Quanto aos capitais políticos, todos os deputados pertenciam ao Partido Republicano Paranaense e atuaram em prol do governo, como base de apoio. Com a Revolução de 1930, os quatro deputados federais foram depostos. Plínio Marques, Arthur Franco e João Garcês perderam o cargo de deputado federal e Eurides Cunha o de Prefeito de Curitiba. A Revolução de 1930 abalou a carreira política deste conjunto de deputados. Plínio Marques, Arthur Franco e Eurides Cunha não tiveram cargos políticos após os acontecimentos de 1930. Apenas João Moreira Garcês obteve cargos após 1930, sendo nomeado prefeito de Curitiba pelo interventor Manoel Ribas em 1938. Tais dados demonstram uma ruptura nas carreiras do conjunto de deputados federais analisados.

O próximo quadro oferecerá informações quanto aos capitais políticos e formativos dos deputados federais eleitos após a Revolução de 1930.

QUADRO 14 - Capitais políticos dos deputados federais eleitos após a Revolução de 1930.

\begin{tabular}{|l|l|l|}
\hline Nome & Formação & Cargos Políticos/períodos \\
\hline Idálio Sardenberg & Militar, RJ & Apoiador da Revolução de 1930; Deputado \\
& & Federal, 1933-1935; Membro do Partido \\
& & Liberal, dissidente do PSD e opositor a \\
& & Manoel Ribas. Membro do Conselho \\
& & Administrativo (DASP), 1935-1937; \\
& & Presidente da Petrobrás, governo JK, 1958; \\
\hline
\end{tabular}


Revista NEP - Núcleo de Estudos Paranaenses, Curitiba, v.5, n.1, jun. 2019

\begin{tabular}{|c|c|c|}
\hline & & $\begin{array}{l}\text { Chefe do Estado-Maior das Forças Armadas } \\
\text { a partir de 1971; }\end{array}$ \\
\hline $\begin{array}{l}\text { Manoel Lacerda } \\
\text { Pinto }\end{array}$ & Direito, SP & $\begin{array}{l}\text { Membro do Conselho Consultivo do Estado } \\
\text { até 1932; Deputado Federal, 1933-1935. }\end{array}$ \\
\hline 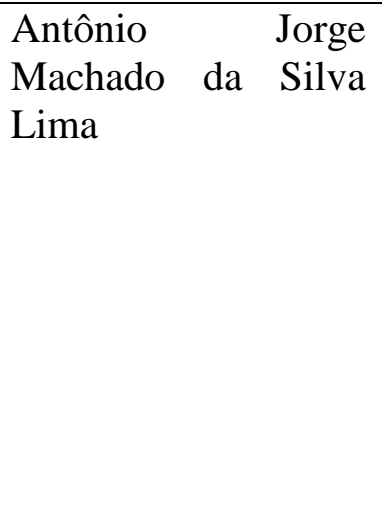 & Direito, SP & $\begin{array}{l}\text { Membro da diretoria do Partido Democrático } \\
\text { Paranaense. Apoiador da Revolução de 1930; } \\
\text { Diretor- geral do Ensino no Paraná, 1930- } \\
\text { 1932; Membro do Conselho Consultivo do } \\
\text { estado, 1932-1935; Deputado Federal, 1933; } \\
\text { Senador, 1935-1937; Membro do Partido } \\
\text { Liberal, dissidente do PSD e opositor a } \\
\text { Manoel Ribas. Procurador do Departamento } \\
\text { de Finanças Públicas, 1939 e Auditor do } \\
\text { Tribunal de Contas da União, desde a década } \\
\text { de 1940. }\end{array}$ \\
\hline Plínio Tourinho & $\begin{array}{l}\text { Engenharia } \\
\text { Militar, RJ }\end{array}$ & $\begin{array}{l}\text { Apoiador da Revolução de 1930; Chefe do } \\
\text { Serviço de Engenharia Regional do Paraná, } \\
\text { 1931; Deputado Federal de } 1933 \text { a 1937, pelo } \\
\text { Partido Liberal. } \\
\text { Nomeado novamente Chefe do Serviço de } \\
\text { Engenharia Regional do Paraná, no ano de } \\
\text { 1938. }\end{array}$ \\
\hline $\begin{array}{l}\text { Francisco de Paula } \\
\text { Soares }\end{array}$ & Medicina, RS & $\begin{array}{l}\text { Apoiador da Revolução de 1930; Deputado } \\
\text { Federal, 1935-1937. Membro do Partido } \\
\text { Liberal, dissidente do PSD e opositor a } \\
\text { Manoel Ribas. }\end{array}$ \\
\hline Lauro Sodré Lopes & Direito, PR & $\begin{array}{l}\text { Apoiador da Revolução de 1930; Deputado } \\
\text { Federal 1935-1937; Deputado Federal, 1946- } \\
\text { 1954. Desembargador do TJ. }\end{array}$ \\
\hline Octávio da Silveira & Medicina, RS & $\begin{array}{l}\text { Apoiador da Revolução de 1930; Diretor } \\
\text { Geral do Ensino e Saúde Pública, } \\
\text { interventoria Manoel Ribas; Deputado } \\
\text { Federal 1935-1937; Líder da Aliança } \\
\text { Nacional Libertadora (ANL) no Paraná. }\end{array}$ \\
\hline Airton Plaisant & Militar & $\begin{array}{l}\text { Apoiador da Revolução de 1930; Opositor a } \\
\text { Mário Tourinho; Deputado Federal 1935- } \\
1937 \text {. }\end{array}$ \\
\hline $\begin{array}{ll}\text { Francisco } & \text { Ferreira } \\
\text { Pereira } & \end{array}$ & $\begin{array}{l}\text { Engenharia } \\
\text { Civil }\end{array}$ & $\begin{array}{l}\text { Apoiador da Revolução de 1930, Deputado } \\
\text { Federal 1935-1937. }\end{array}$ \\
\hline $\begin{array}{l}\text { Arthur Ferreira dos } \\
\text { Santos }\end{array}$ & Direito, SP & $\begin{array}{l}\text { Oficial de Gabinete, } 1^{\circ} \text { gestão de Affonso } \\
\text { Camargo; Deputado Federal 1935-1937. }\end{array}$ \\
\hline
\end{tabular}

Fontes: NEGRÃO; OLIVEIRA, 2000, 1997; NICOLAS, 1977; DHBB CPDOC FGV.

Dos dez deputados federais eleitos para a Assembleia Nacional Constituinte, em 1933, e para o Congresso Nacional, em 1934, temos um conjunto de quatro deputados formados em Direito, três com formação militar, dois em Medicina e um em Engenharia 
Civil. Comparando-se estes agentes em relação ao período anterior, assinalamos o prestígio militar nos cargos políticos. Também assinalamos a importância do apoio e a participação no movimento revolucionário de 1930 para a potencialização das suas carreiras políticas. Oito dos dez deputados federais participaram ativamente dos acontecimentos de 1930. Tratase de uma classe política nova, visto que nove dos dez deputados não tinham cargos políticos antes de 1930.

Uma recorrência desta amostra refere-se ao número de deputados do Partido Social Democrático. O PSD é o partido de oito dos dez deputados federais, o que demonstra um amplo apoio ao governo e a interventoria de Manoel Ribas. Os dois deputados que não pertenciam ao PSD eram Plínio Tourinho e Arthur Ferreira dos Santos. Plínio Tourinho pertencia ao Partido Liberal, e se desgastou com as forças políticas dominantes do estado a partir da crise que levou a destituição do seu irmão Mário Tourinho da interventoria federal do Paraná. Ambos foram líderes da Revolução de 1930 no Paraná, que se desgastaram com o processo político posterior ao movimento. Já Arthur Ferreira dos Santos pertencia a União Republicana Paranaense, a URP, agremiação que aglutinava os políticos remanescentes do período pré-1930. Não por acaso, trata-se do único entre os deputados federais analisados em exercer cargos no período anterior a 1930, como oficial de gabinete de Affonso Camargo, presidente do Paraná deposto pela Revolução de 1930.

Outro dado que destacamos refere-se a ocupação de cargos no conselho administrativo do estado, o DASP. Três dos oito deputados do PSD foram membros de tal órgão (Idálio Sardenberg, Manoel Lacerda Pinto e Antônio Jorge Machado da Silva Lima).

Destacam-se as novidades referentes a representação classista a partir da década de 1930. Um notável deputado foi Octávio da Silveira, médico que havia sido diretor de Saúde Pública e secretário da educação na interventoria de Manoel Ribas antes de ocupar o posto de deputado. Sua atuação no campo das lutas sociais e da defesa da classe operária foi notável, sendo apoiador dos movimentos tenentistas de 1922, 1924 e da Coluna Prestes. Também apoiou a Revolução de 1930 no Paraná. No entanto, no desenrolar do governo provisório de Vargas, passou para a oposição, tornando-se integrante do Diretório Central da ANL no Rio de Janeiro, então Distrito Federal. Na tribuna da Câmara dos Deputados, leu, no dia 06 de julho de 1935, o Manifesto de Luís Carlos Prestes, "Todo poder à ANL", que conclamava à insurreição popular. Como resposta, Vargas decretou o fechamento da organização. Octávio da Silveira foi Presidente da ANL e companheiro de militância de 
Francisco Mangabeira, Abguar Bastos, Maurício de Lacerda, Filipe Moreira Lima, Roberto Sisson, membros da organização Aliança Popular por Pão, Terra e Liberdade, que substituiu a ANL (TEIVE, 2008).

Opositor às arbitrariedades cometidas por Getúlio Vargas contra o Levante Comunista de 1935. Preso em 1936 juntamente com os deputados Domingos Velasco, Abguar Bastos e João Mangabeira e o senador Abel Chermont. Depois do término da sua pena, Otávio da Silveira voltou a desempenhar suas funções legislativas, interrompidas com o golpe de 1937 (TEIVE, 2008). Após o final do Estado Novo, filiou-se ao Partido Comunista, sendo expulso da agremiação em 1946 (MONTEIRO, 2013, p.173).

Nesta visualização de carreiras políticas dos deputados federais eleitos no pleito anterior a 1930 e as carreiras dos deputados federais eleitos em 1933 e 1934, assinalamos que algumas mudanças de perfis políticos são notáveis, tais como a incorporação de grupos não hegemônicos na cena política, que inclui ex-membros do Partido Democrático Paranaense (como Antônio Jorge Machado da Silva Lima), nacionalistas de esquerda, como Octávio da Silveira, dissidentes do processo posterior a Revolução de 1930, que inicialmente atuaram na linha de frente do projeto revolucionário, como Plínio Tourinho, além de remanescentes oligarcas fortemente ligados ao período pré-1930, como Arthur Santos. Entre os deputados federais, nenhum integralista se elegeu.

A próxima seção analisará o perfil político dos deputados estaduais eleitos durante o processo político que envolveu a Revolução de 1930.

\section{Comparação entre os perfis políticos dos deputados estaduais eleitos antes e depois da}

\section{Revolução de 1930}

O quadro a seguir tratará do perfil político dos deputados estaduais eleitos antes da Revolução de 1930, cujos mandatos foram atravessados pelo movimento revolucionário.

QUADRO 15 - Capitais políticos dos deputados estaduais com mandato em 1930

\begin{tabular}{|l|l|l|}
\hline Nome & Formação & Cargos Políticos/períodos \\
\hline Caio Gracho & Ciência & Delegado Técnico do Ensino Público; \\
Machado de Lima & Política, Paris & $\begin{array}{l}\text { Deputado Estadual 1908-1909; 1929-1930; } \\
\text { 1935-1937. Juiz do Tribunal de Contas do } \\
\end{array}$ \\
& & Estado desde 1947; \\
\hline
\end{tabular}


Revista NEP - Núcleo de Estudos Paranaenses, Curitiba, v.5, n.1, jun. 2019

\begin{tabular}{|c|c|c|}
\hline \multirow{2}{*}{$\begin{array}{l}\text { Dídio Iratym } \\
\text { Affonso da Costa }\end{array}$} & Engenharia & Prefeito de Paranaguá, 1927-1930; Deputado \\
\hline & Naval, RJ & $\begin{array}{l}\text { Estadual, 1924-1925; 1926-1927; 1929- } \\
\text { 1930; } 1930 .\end{array}$ \\
\hline Domingos de Freitas & & $\begin{array}{l}\text { Prefeito de Palmeira; Deputado Estadual, } \\
\text { 1924-1925; }\end{array}$ \\
\hline Edmundo Mercer & $\begin{array}{l}\text { Humanidades, } \\
\text { PR }\end{array}$ & $\begin{array}{l}\text { Prefeito de Tibagi; Deputado Estadual, 1929- } \\
1930\end{array}$ \\
\hline Elbe Lauro Pospissil & & $\begin{array}{l}\text { Deputado Estadual, 1896; Deputado Estadual } \\
\text { 1930; Deputado Estadual 1935-1937; }\end{array}$ \\
\hline $\begin{array}{l}\text { Enéas Marques dos } \\
\text { Santos }\end{array}$ & Direito, SP & $\begin{array}{l}\text { Secretário do Interior, Justiça e Instrução } \\
\text { Pública, 1916-1918; Deputado Estadual, } \\
\text { 1929-1930. }\end{array}$ \\
\hline Ermelino Beckert & Magistério & Deputado Estadual, 1929-1930. \\
\hline $\begin{array}{l}\text { Ermelino Agostinho } \\
\text { de Leão }\end{array}$ & Direito, SP & $\begin{array}{l}\text { Deputado estadual, 1897-1898; 1889; 1897- } \\
1898 ; 1929-1930\end{array}$ \\
\hline $\begin{array}{l}\text { Estevam Ribeiro do } \\
\text { Nascimento Júnior }\end{array}$ & Secundário, PR & $\begin{array}{l}\text { Prefeito de Clevelândia; Deputado estadual, } \\
\text { 1929-1930; }\end{array}$ \\
\hline $\begin{array}{ll}\text { Francisco } & \text { Fido } \\
\text { Fontana } & \end{array}$ & Secundário, RJ & $\begin{array}{l}\text { Chefe político em Ipiranga (PR); Deputado } \\
\text { Estadual (1908-1911/1924-1930). }\end{array}$ \\
\hline $\begin{array}{l}\text { Francisco Ribeiro de } \\
\text { Azevedo Macedo }\end{array}$ & Direito & $\begin{array}{l}\text { Oficial de Gabinete de Vicente Machado; } \\
\text { Deputado Estadual 1920-1923; Deputado } \\
\text { Estadual, 1930; }\end{array}$ \\
\hline $\begin{array}{l}\text { Genaro Régis Pereira } \\
\text { da Costa }\end{array}$ & Direito & Deputado Estadual 1929-1930 \\
\hline $\begin{array}{l}\text { Hernani Nogueira } \\
\text { Zaina }\end{array}$ & Militar & $\begin{array}{l}\text { Deputado Estadual, 1926-1930. Apoiador da } \\
\text { Revolução de } 1930 .\end{array}$ \\
\hline $\begin{array}{l}\text { Hildebrando Cézar } \\
\text { de Souza Araujo }\end{array}$ & Secundário & $\begin{array}{l}\text { Prefeito de Ipiranga; Deputado Estadual, } \\
\text { 1916-1921; 1926-1930. }\end{array}$ \\
\hline João Antônio Xavier & Direito & $\begin{array}{l}\text { Procurador da Delegacia Fiscal do Tesouro, } \\
\text { 1894; Deputado Estadual, 1900-1901; 1910- } \\
\text { 1911; 1922-1923; 1929-1930; Vereador e } \\
\text { Presidente da Câmara Municipal de Curitiba } \\
\text { (1908); Prefeito Interino de Curitiba por duas } \\
\text { ocasiões: 1912-1913 e 1920. }\end{array}$ \\
\hline $\begin{array}{l}\text { João Cândido de } \\
\text { Oliveira }\end{array}$ & Primário, PR & $\begin{array}{l}\text { Prefeito de Almirante Tamandaré; Deputado } \\
\text { Estadual, 1912-1913; } 1930 .\end{array}$ \\
\hline João Fleury da Rocha & Direito $(\mathrm{RJ})$ & $\begin{array}{l}\text { Prefeito de Prudentópolis, } 1928-1930 ; \\
\text { Deputado Estadual 1920-1921; 1924-1925; } \\
1930 .\end{array}$ \\
\hline $\begin{array}{l}\text { João Leite de Paula e } \\
\text { Silva }\end{array}$ & Direito $(\mathrm{PE})$ & $\begin{array}{l}\text { Chefe político em Tomazina; Deputado } \\
\text { Estadual, 1896-1898; Deputado Federal pela } \\
\text { Paraíba de 1903 a 1908; Deputado Estadual } \\
1910-1915 ; 1929-1930\end{array}$ \\
\hline João Sampaio & & Deputado Estadual, 1910-1930. \\
\hline $\begin{array}{l}\text { Leovigildo Barbosa } \\
\text { Ferraz }\end{array}$ & $\begin{array}{l}\text { Comércio, } \\
\text { França }\end{array}$ & Deputado Estadual (1928-1930) \\
\hline
\end{tabular}


Revista NEP - Núcleo de Estudos Paranaenses, Curitiba, v.5, n.1, jun. 2019

\begin{tabular}{|l|l|l|}
\hline $\begin{array}{l}\text { Lysandro Alves de } \\
\text { Araujo }\end{array}$ & $\begin{array}{l}\text { Escola Naval } \\
\text { (RJ) }\end{array}$ & $\begin{array}{l}\text { Prefeito em Ponta Grossa; Deputado } \\
\text { Estadual (1928-1930) }\end{array}$ \\
\hline $\begin{array}{l}\text { Manoel de Oliveira } \\
\text { Franco }\end{array}$ & Direito (SP) & $\begin{array}{l}\text { Secretário dos Negócios do Interior, Justiça e } \\
\text { Instrução Pública, 1919; Secretário dos } \\
\text { Negócios da Fazenda, Indústria e Comércio; } \\
\text { Deputado Estadual, 1922-1930. }\end{array}$ \\
\hline $\begin{array}{l}\text { Romualdo Antônio } \\
\text { Baraúna }\end{array}$ & $\begin{array}{l}\text { Engenharia } \\
\text { Agrônoma } \\
\text { (BA) }\end{array}$ & $\begin{array}{l}\text { Deputado Estadual entre 1908 e 1930. } \\
\text { Ocupou a presidência da casa em diversos } \\
\text { momentos; Prefeito de Guarapuava, 1921- } \\
1924 .\end{array}$ \\
\hline $\begin{array}{l}\text { Sylvano Alves da } \\
\text { Rocha Loures }\end{array}$ & $\begin{array}{l}\text { Engenharia } \\
\text { Agrônoma } \\
\text { (SP) }\end{array}$ & \begin{tabular}{l} 
Deputado Estadual, 1929-1930 \\
\hline Tasso da Silveira
\end{tabular} Direito (RJ) \\
\hline $\begin{array}{l}\text { Theóphilo Soares } \\
\text { Gomes }\end{array}$ & & $\begin{array}{l}\text { Prefeito de Antonina; Deputado Estadual, } \\
\text { 1891; 1904-1905; 1924-1925; 1929-1930. }\end{array}$ \\
\hline Vespasiano de Mello & Primário & $\begin{array}{l}\text { Vereador em Castro. Prefeito de Castro; } \\
\text { Deputado Estadual, 1930 }\end{array}$ \\
\hline Wallace de Mello & Medicina & $\begin{array}{l}\text { Camarista em Curitiba; Deputado Estadual } \\
\text { (1914-1915); 1930. }\end{array}$ \\
\hline
\end{tabular}

Fontes: NEGRÃO; OLIVEIRA, 2000, 1997; NICOLAS, 1984; ALEP.

$\mathrm{Na}$ análise dos capitais políticos dos deputados estaduais que tiveram os seus mandatos atravessados pela Revolução de 1930, destaca-se o fato de que todos pertenciam ao Partido Republicano. No que se refere a formação destes 28 agentes, assinalamos que 9 se formaram em Direito, o que indica a aproximação entre o bacharelismo e a política brasileira no período analisado.

Outras formações referem-se à Engenharia Agrônoma (2 deputados), à formação naval (2 deputados), às humanidades, ciência política e ao magistério (3 deputados), à Escola de Negócios (1 deputado) e à Medicina (1 deputado). Um conjunto de 3 deputados se formaram no secundário e 2 se formaram no primário. Não obtivemos informações de formação de 5 deputados estaduais do período. Apenas um deputado (Hernani Zaina, que inclusive foi um dos apoiadores da Revolução de 1930) tinha formação militar, o que contrasta com o cenário político pós-1930, que registra o crescimento da categoria na cena política.

Analisando a carreira política dos 28 deputados estaduais que tiveram o mandado atravessado pela Revolução de 1930, observamos que apenas dois tiveram continuidade em suas carreiras políticas. São eles: Caio Gracho Machado da Silva Lima e Elbe Lauro Pospissil. Caio Gracho Machado da Silva Lima é filho do ex-presidente do Paraná, Vicente 
Machado da Silva Lima, e irmão de Antônio Jorge Machado da Silva Lima, deputado federal e senador pelo Paraná, dissidente do Partido Republicano Paranaense, ex-membro do Partido Democrático e apoiador da Revolução de 1930. Os irmãos Caio e Antônio Jorge são figuras de famílias tradicionais do estado e também associados a figura hegemônica de Vicente Machado na política paranaense, com grande poder e influência no legislativo e no executivo estadual. Porém, com o passar dos anos e a consolidação do Partido Republicano Paranaense, viram-se no ostracismo e na decadência de suas carreiras políticas, incrementadas apenas no final da década de 1920, com a ascensão de grupos de oligarcas dissidentes, e principalmente com a Revolução de 1930, que consolidou a carreira política de ambos. Caio Machado foi eleito deputado estadual para a constituinte de 1935 e nomeado juiz do Tribunal de Contas do Estado na ocasião de sua criação, no ano de 1947.

Já Elbe Lauro Pospissil é o único deputado estadual defensor da causa dos operários do Paraná. Sua atuação como deputado estadual começou em 1896, quando pertencia ao Partido Republicano Federal. Na última eleição legislativa antes da Revolução de 1930, foi eleito novamente para a Assembleia Legislativa. Mesmo com a cassação de todos os deputados estaduais pela revolução, Elbe Pospissil foi eleito novamente para exercer mandato a partir de 1935. Como deputado classista, atuava na Sociedade Protetora dos Operários e era redator dos jornais "O Proletário", "O Trabalho", "A Tribuna" e "Revista do Sul” (NICOLAS, 1984; GOULART, 2008).

A trajetória de ambos indica a tendência a novos estilos políticos de atuação no período pós-1930, associados a organização política de oligarcas dissidentes e a representatividade da classe operária no legislativo estadual. Os demais deputados não tinham estes capitais associados a lógica de reprodução e poder do período pós-1930, e não tiveram continuidades nas suas respectivas carreiras no legislativo estadual.

Voltando a análise dos deputados estaduais do período pré-1930, assinalamos a atuação municipal de alguns deputados estaduais, decisivas no desenvolvimento de suas carreiras políticas na Primeira República. Destacamos a atuação de Dídio Affonso da Costa, em Paranaguá; Domingos de Freitas, em Palmeira; Edmundo Mercer, em Tibagi; Estevam Ribeiro do Nascimento Júnior, em Clevelândia; Francisco Fido Fontana, em Ipiranga; Hildebrando de Araújo, em Ipiranga, João Antônio Xavier, em Curitiba, João Cândido de Oliveira, em Almirante Tamandaré, João Fleury da Rocha, em Prudentópolis, João Leite de Paula e Silva, em Tomazina, Lysandro Alves de Araújo, em Ponta Grossa, Romualdo 
Antônio Baraúna, em Guarapuava, Theóphilo Soares Gomes, em Antonina e Wallace de Mello, em Curitiba. Destes 14 deputados estaduais, 10 combinaram suas atividades nos munícipios com mais de um ou diversos mandatos na Assembleia Legislativa.

Tais atuações associavam-se ao fenômeno do coronelismo. Mônica Goulart (2015), embasando-se em Vitor Nunes Leal, assinala que o fenômeno ocorreu no Paraná a partir de uma relação de troca de favores entre os coronéis, representantes do poder privado, que controlavam os votos das populações rurais pobres em seus municípios, e os governantes estaduais, representantes do poder público. Os coronéis e chefes municipais estavam submetidos aos agentes públicos estaduais, que tiveram os seus poderes fortalecidos durante a Primeira República.

Já os deputados estaduais que tiveram mais de um ou muitos mandatos na ALEP sem exercerem mandatos em municípios se referem aos seguintes: Caio Gracho Machado da Silva Lima, Elbe Pospissil, Ermelino de Leão, Francisco Ribeiro de Macedo. Tratam-se de deputados com carreira na ALEP desassociadas dos municípios.

Combinaram suas carreiras com o exercício de cargos no secretariado do poder executivo os deputados Enéas Marques dos Santos e Manoel de Oliveira Franco. Nestes casos, não estamos tratando de coronéis e chefes municipais que alcançam o legislativo paranaense, mas agentes políticos altamente incorporados a elite política local nos poderes executivo e legislativo. Enéas Marques dos Santos era filho de Generoso Marques dos Santos, importante político do período imperial, presidente do estado no ano de 1891, deputado estadual e senador, cargo em que se manteve até 1926 (CARNEIRO; VARGAS, 1994). Enéas Marques dos Santos foi secretário do Interior, Justiça e Instrução Pública no primeiro governo de Affonso Camargo, entre 1916 e 1918, além de deputado estadual. Já Manoel de Oliveira Franco era membro de uma das mais tradicionais famílias do Paraná, sendo portador do título Rodrigues Seixas (NEGRÃO, 1927), exercendo cargos como as secretarias dos Negócios do Interior, Justiça e Instrução Pública e dos Negócios da Fazenda, Indústria e Comércio. $\mathrm{Na}$ Assembleia Legislativa, se notabilizou como $1^{\circ}$ secretário e líder da maioria.

Em linhas gerais, estas são as características centrais do padrão de carreiras desenvolvidas pelos deputados estaduais que tiveram seus mandatos atravessados pela Revolução de 1930. No próximo quadro, visualizaremos as informações de formação e carreiras políticas dos deputados estaduais eleitos após a Revolução de 1930, com a novidade 
Revista NEP - Núcleo de Estudos Paranaenses, Curitiba, v.5, n.1, jun. 2019

dos mesmos estarem separados por partidos políticos, recém-criados no período provisório de Getúlio Vargas.

QUADRO 16 - Capitais políticos dos deputados estaduais do PSD eleitos após 1930

\begin{tabular}{|c|c|c|}
\hline Nome & Formação & Cargos Políticos/períodos \\
\hline $\begin{array}{l}\text { Antônio Augusto de } \\
\text { Carvalho Chaves }\end{array}$ & Direito (SP) & $\begin{array}{l}\text { Secretário do Interior, Justiça e Instrução } \\
\text { Pública, governo de Francisco Xavier da } \\
\text { Silva; Secretário de Finanças, Comércio e } \\
\text { Indústria, 1900-1904; Deputado federal, } \\
\text { 1904- 1914 Acumulou o cargo de deputado } \\
\text { estadual em alguns anos deste período. } \\
\text { Membro da diretoria do Partido Democrático } \\
\text { Paranaense. Apoiador da Revolução de } 1930 . \\
\text { Secretário da Fazenda, Comércio e Indústria } \\
\text { de } 1930 \text { a 1931, nas interventorias de Mário } \\
\text { Tourinho e João Perneta; Deputado estadual } \\
\text { em 1934. } \\
\text { Interventor interino entre junho e julho de } \\
\text { 1935; Membro do Conselho Administrativo } \\
\text { (DASP) a partir de 1937. }\end{array}$ \\
\hline Acyr Guimarães & Secundário & $\begin{array}{l}\text { Apoiador da Revolução de 1930. Deputado } \\
\text { estadual, 1935-1937. Deputado Federal } \\
\text { (PSD) 1946-1948. }\end{array}$ \\
\hline Adalberto Scherer & Primário & Deputado Estadual, 1935-1937 \\
\hline $\begin{array}{l}\text { Agostinho Pereira } \\
\text { Alves Filho }\end{array}$ & & $\begin{array}{l}\text { Apoiador da Revolução de 1930. Deputado } \\
\text { Estadual, 1935-1937 Participou da Aliança } \\
\text { Nacional Libertadora. }\end{array}$ \\
\hline Alceu Ferreira & Medicina (RJ) & $\begin{array}{l}\text { Diretor Geral da Saúde Pública do Paraná; } \\
\text { Diretor da Saúde de Curitiba; Deputado } \\
\text { Estadual, 1935-1937 }\end{array}$ \\
\hline Augusto Santos & & Deputado Estadual, 1935-1937 \\
\hline $\begin{array}{ll}\text { Brasil } & \text { Pinheiro } \\
\text { Machado } & \end{array}$ & Direito $(\mathrm{RJ})$ & $\begin{array}{l}\text { Prefeito de Ponta Grossa, 1932-1935 } \\
\text { Deputado Estadual, 1935-1937; Procurador } \\
\text { Geral do Estado a partir de 1939; Interventor } \\
\text { do Paraná, 1947; Conselheiro do Tribunal de } \\
\text { Contas do Estado a partir de 1947; Deputado } \\
\text { Federal (PSD), 1947-1951. }\end{array}$ \\
\hline $\begin{array}{l}\text { Caio Gracho } \\
\text { Machado de Lima }\end{array}$ & $\begin{array}{l}\text { Ciência } \\
\text { Política (Paris) }\end{array}$ & $\begin{array}{l}\text { Delegado Técnico do Ensino Público; } \\
\text { Deputado Estadual 1908-1909; 1929-1930; } \\
\text { 1935-1937. Juiz do Tribunal de Contas do } \\
\text { Estado desde 1947; }\end{array}$ \\
\hline Camilo Stellfeld & Farmácia (PR) & Deputado Estadual, 1935-1937. \\
\hline $\begin{array}{l}\text { Djalma Rocha Al- } \\
\text { Chueyr }\end{array}$ & Economia (SP) & $\begin{array}{l}\text { Apoiador da Revolução de } 1930 \text {. Deputado } \\
\text { Estadual, 1935-1937. Participou da Aliança } \\
\text { Nacional Libertadora; Crítico do Estado }\end{array}$ \\
\hline
\end{tabular}


Revista NEP - Núcleo de Estudos Paranaenses, Curitiba, v.5, n.1, jun. 2019

\begin{tabular}{|c|c|c|}
\hline & & $\begin{array}{l}\text { Novo, abandonou a política e mudou-se para } \\
\text { o Rio de Janeiro. }\end{array}$ \\
\hline Erasto Gaertner & Medicina $(\mathrm{RJ})$ & $\begin{array}{l}\text { Apoiador da Revolução de 1930. Deputado } \\
\text { Estadual, 1935-1937; Com o final do Estado } \\
\text { Novo, foi um dos fundadores da UDN e } \\
\text { Deputado Constituinte de 1946; Deputado } \\
\text { Federal, UDN, 1946-1951. Secretário da } \\
\text { Fazenda do Paraná em 1951; Nomeado } \\
\text { Prefeito de Curitiba pelo governador Bento } \\
\text { Munhoz da Rocha. }\end{array}$ \\
\hline $\begin{array}{l}\text { Frederico Faria de } \\
\text { Oliveira }\end{array}$ & Secundário & $\begin{array}{l}\text { Apoiador da Revolução de 1930. Deputado } \\
\text { Estadual, 1935-1937. }\end{array}$ \\
\hline $\begin{array}{l}\text { Helvídio da Silva } \\
\text { Pereira }\end{array}$ & Direito (PE) & 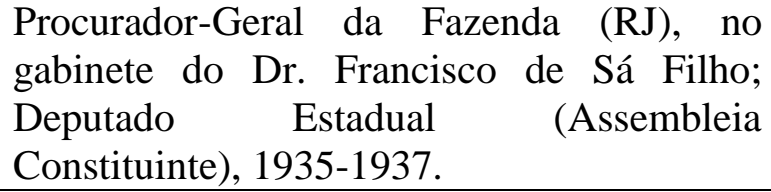 \\
\hline $\begin{array}{l}\text { João Theophilo } \\
\text { Gomy Júnior }\end{array}$ & Direito (PR) & $\begin{array}{l}\text { Vereador e presidente da Câmara Municipal } \\
\text { de União da Vitória; Deputado Estadual } \\
\text { (Assembleia Constituinte), 1935-1937; } \\
\text { Secretário do Interior, Justiça e Segurança } \\
\text { Pública, governo Lupion }\end{array}$ \\
\hline $\begin{array}{l}\text { José Manoel Ribeiro } \\
\text { dos Santos }\end{array}$ & Medicina (PR) & $\begin{array}{l}\text { Deputado Estadual, 1935-1937; Diretor da } \\
\text { Saúde Pública, Deputado Estadual, 1947- } \\
\text { 1950; }\end{array}$ \\
\hline $\begin{array}{ll}\text { Linneu } & \text { Madureira } \\
\text { Novais } & \\
\end{array}$ & Medicina (PR) & $\begin{array}{l}\text { Deputado Estadual, 1935-1937; Deputado } \\
\text { Estadual, 1947-1950. }\end{array}$ \\
\hline Mário Erichsen & $\begin{array}{l}\text { Engenharia } \\
\text { Civil (PR) }\end{array}$ & $\begin{array}{l}\text { Prefeito de Antonina, 1933; Deputado } \\
\text { Estadual, 1935-1937;Chefe do Departamento } \\
\text { de Águas em Jacarezinho até 1945. }\end{array}$ \\
\hline Nelson José Corrêa & $\begin{array}{l}\text { Odontologia } \\
\text { (PR) }\end{array}$ & Deputado Estadual 1935-1937. \\
\hline $\begin{array}{l}\text { Oscar Borges de } \\
\text { Macedo Ribas }\end{array}$ & Direito (PR) & $\begin{array}{l}\text { Deputado Estadual, 1935-1937; Secretário da } \\
\text { Fazenda, 1937-1938; Secretário do Interior e } \\
\text { Justiça, 1938; Prefeito Municipal de Curitiba, } \\
\text { 1938; Presidente do Conselho Deliberativo } \\
\text { do Estado (DASP); Deputado Federal, 1948- } \\
\text { 1949; }\end{array}$ \\
\hline $\begin{array}{l}\text { Ovande Ferreira do } \\
\text { Amaral e Silva }\end{array}$ & Medicina $(\mathrm{RJ})$ & $\begin{array}{l}\text { Apoiador da Revolução de 1930; Deputado } \\
\text { Estadual, 1935-1937; 1947-1948. Presidente } \\
\text { da ALEP. }\end{array}$ \\
\hline Raul Gomes Pereira & $\begin{array}{l}\text { Contabilidade } \\
\text { (PR) }\end{array}$ & $\begin{array}{l}\text { Deputado Estadual, 1935-1937; Secretário } \\
\text { geral do Território do Iguaçu, 1944-1946. }\end{array}$ \\
\hline Alfredo Venske & & Deputado Estadual, 1935-1937. \\
\hline
\end{tabular}

Fontes: NEGRÃO; OLIVEIRA, 2000, 1997; NICOLAS, 1984; ALEP. 
Revista NEP - Núcleo de Estudos Paranaenses, Curitiba, v.5, n.1, jun. 2019

Nas eleições de 1935, o Partido Social Democrático elegeu a maior bancada para a Assembleia Legislativa, fazendo com que o interventor Manoel Ribas obtivesse um amplo apoio no estado. Dos 32 deputados eleitos, 23 pertenciam à bancada do PSD.

O perfil de formação dos deputados do PSD se configura da seguinte maneira: 5 deputados eram formados em Direito, 5 em Medicina, 3 possuíam o primário e secundário e 6 em cursos superiores diversos. Não obtivemos informações de formação de 4 deputados estaduais.

Dos 23 deputados da bancada do PSD, 7 atuaram decisivamente em prol da Revolução de 1930, sendo eles: Antônio Augusto Carvalho Chaves, Acyr Guimarães, Agostinho Pereira Alves Filho, Djalma Rocha Al-Chueyr, Erasto Gaertner, Frederico Faria de Oliveira e Ovande Ferreira do Amaral e Silva. Deste grupo de apoiadores, houve dissidências críticas em relação aos rumos que a revolução tomou. Nesse sentido, destacamos as atuações de Agostinho Pereira Filho e Djalma Al-Chueyr, membros da Aliança Nacional Libertadora. Também assinalamos a atuação de Erasto Gaertner, um dos críticos locais do Estado Novo e fundador da União Democrática Nacional.

Quanto a análise da carreira política destes deputados, verificamos que apenas 3 dos 23 deputados estaduais tinham cargos ou mandatos políticos antes da Revolução de 1930. Isso indica uma classe política nova, ainda que a mesma seja ligada às velhas classes dominantes através do parentesco. Os três deputados referem-se a Caio Gracho Machado de Lima, Elbe Pospissil e Antônio Carvalho Chaves. O primeiro, conforme o visto na seção anterior, era familiarmente ligado a grupos de oligarcas dissidentes no período pré-1930. O segundo era uma importante liderança operária. Já o terceiro, Antônio Augusto Carvalho Chaves era um dos dirigentes e fundadores do Partido Democrático Paranaense, dissidência oligárquica que surgiu no estado no ano de 1927. Sua carreira política é de longa duração, ocupado secretarias de governos da República Velha e das interventorias do período pós1930, além de exercer os cargos de deputado federal e estadual. Seu prestígio político foi consolidado com o Estado Novo, quando passou a ocupar uma vaga no Conselho Administrativo (DASP), a partir de 1937 (DAGOSTIM, 2011; DHBB CPDOC FGV; CARNEIRO; VARGAS, 1994, GOULART, 2008).

Dos 23 deputados do PSD, 4 exerceram cargos em municípios, sendo eles: Brasil Pinheiro Machado, em Ponta Grossa, João Theophilo Gomy Júnior, em União da Vitória, Mario Erichsen, em Antonina e Oscar Borges de Macedo Ribas, em Curitiba. Isso indica 
Revista NEP - Núcleo de Estudos Paranaenses, Curitiba, v.5, n.1, jun. 2019

uma redução da influência da municipalidade e dos chefes políticos locais na ocupação de cargos no legislativo estadual.

Outro fenômeno observado corresponde a recorrência de deputados do PSD que ocuparam mais de um mandato no legislativo estadual ou federal. Dos 23 deputados listados, 9 se enquadram nesta categoria.

O quadro a seguir oferece informações a respeito dos capitais formativos e políticos da bancada da União Republicana Paranaense.

QUADRO 17 - Capitais políticos dos deputados estaduais da URP eleitos após 1930

\begin{tabular}{|c|c|c|}
\hline Nome & Formação & Cargos Políticos/períodos \\
\hline $\begin{array}{l}\text { Caetano Munhoz da } \\
\text { Rocha }\end{array}$ & Medicina $(\mathrm{RJ})$ & $\begin{array}{l}\text { Deputado Estadual, de } 1904 \text { a 1917. Prefeito } \\
\text { de Paranaguá, 1908-1912; 1912-1915. Vice- } \\
\text { presidente do Paraná, 1916-1920; Secretário } \\
\text { da Fazenda, Agricultura e Obras Públicas } \\
\text { (Governo Affonso Camargo), Presidente do } \\
\text { Paraná, 1920-1928, Senador, 1928-1930. } \\
\text { Afastado pela Revolução de 1930, foi eleito } \\
\text { deputado estadual pela União Republicana } \\
\text { Paranaense (reunião de políticos do período } \\
\text { anterior à 1930), cassado em } 1937 . \\
\text { Presidente do Departamento Administrativo } \\
\text { do Estado de 1939 a 1940. }\end{array}$ \\
\hline $\begin{array}{l}\text { Alcides } \quad \text { Pereira } \\
\text { Júnior }\end{array}$ & Direito (PR) & $\begin{array}{l}\text { Deputado Estadual, 1935-1937; Procurador } \\
\text { Geral do Estado, 1946; Deputado Estadual, } \\
\text { 1947-1950; Procurador Fiscal do Tribunal de } \\
\text { Contas do Estado. }\end{array}$ \\
\hline $\begin{array}{l}\text { Carlos Ribeiro de } \\
\text { Macedo }\end{array}$ & Medicina (PR) & $\begin{array}{l}\text { Prefeito de } \text { Teixeira } \text { Soares; } \\
\text { Estadual, 1935-1937; }\end{array}$ \\
\hline $\begin{array}{l}\text { Laertes de Macedo } \\
\text { Munhoz }\end{array}$ & Direito (PR) & $\begin{array}{l}\text { Prefeito de Teixeira Soares; Deputado } \\
\text { Estadual, 1935-1937; Deputado Estadual, } \\
\text { 1947-1950; Deputado Estadual, 1950-1954; }\end{array}$ \\
\hline $\begin{array}{l}\text { Lindolpho Pessoa da } \\
\text { Cruz Marques }\end{array}$ & Direito (PE) & $\begin{array}{l}\text { Delegado de Polícia de Curitiba, governo } \\
\text { Vicente Machado; Chefe de Polícia, governo } \\
\text { Affonso Camargo; Deputado Federal, 1921; } \\
\text { Deputado Estadual, 1935-1937. }\end{array}$ \\
\hline
\end{tabular}

Fontes: NEGRÃO; OLIVEIRA, 2000, 1997; NICOLAS, 1984; ALEP.

Todos os cinco deputados estaduais da União Republicana Paranaense possuíam formação superior. Três deles em Direito e dois em Medicina. Quanto a carreira política dos mesmos, três começaram a ocupar cargos após a Revolução de 1930. Eles se referem a Alcides Pereira Júnior, Carlos Ribeiro de Macedo e Laertes de Macedo Munhoz. Dois deles 
ocupavam cargos políticos na Primeira República. São eles: Caetano Munhoz da Rocha e Lindolpho Pessoa da Cruz Marques.

A URP é um partido que surgiu no Paraná para exercer oposição a Manoel Ribas e ao PSD. Seu presidente era Caetano Munhoz da Rocha, um dos mais importantes chefes políticos estaduais do período pré-1930, presidente do Paraná por dois mandatos. Na análise do perfil social dos seus integrantes, visualizamos membros de famílias dominantes no Paraná no período pré-1930 e agentes políticos que tiveram seus capitais fortemente abalados com a Revolução de 1930. No entanto, os mesmos ressignificaram seus capitais políticos no período pós-1930, angariando importantes cargos e dando continuidade as suas trajetórias, inclusive no período posterior ao Estado Novo. A presença de membros da URP, identificados com os anseios dos grupos dominantes da Primeira República, no contexto da política pós-1930 é mais um traço que assinala o fenômeno da modernização conservadora na política paranaense.

O próximo quadro oferece informações sobre os capitais políticos e de formação da bancada estadual do Partido Social Nacionalista.

QUADRO 18 - Capitais políticos dos deputados estaduais do PSN eleitos após 1930

\begin{tabular}{|c|c|c|}
\hline Nome & Formação & Cargos Políticos/períodos \\
\hline $\begin{array}{ll}\text { Antônio } & \text { Couto } \\
\text { Pereira } & \\
\end{array}$ & Militar & $\begin{array}{l}\text { Apoiador da Revolução de 1930. Deputado } \\
\text { Estadual, 1935-1937. }\end{array}$ \\
\hline $\begin{array}{l}\text { Joaquim Pereira de } \\
\text { Macedo }\end{array}$ & & $\begin{array}{l}\text { Nomeado pela Princesa Isabel coronel } \\
\text { comandante superior da Guarda Nacional no } \\
\text { município de Palmeira; Delegado de polícia, } \\
\text { prefeito e vice-prefeito em Palmeira; } \\
\text { Deputado constituinte, vice-governador do } \\
\text { Paraná, deputado estadual na primeira } \\
\text { legislatura republicana e presidente da } \\
\text { Assembleia Legislativa; Fundador e dirigente } \\
\text { do Partido Democrático Paranaense. } \\
\text { Apoiador da Revolução de 1930. Vereador e } \\
\text { Prefeito de Curitiba em duas legislaturas: de } \\
1908 \text { a 1911 e de } 1930 \text { a 1932 (Prefeito } \\
\text { Revolucionário). Deputado Estadual, 1935- } \\
\text { 1937; }\end{array}$ \\
\hline Jorge Becher & & $\begin{array}{l}\text { Vice-Presidente da Câmara dos Vereadores } \\
\text { de Ponta Grossa, em } 1916 \text { e 1924. Apoiador } \\
\text { da Revolução de 1930, Prefeito de Ponta } \\
\text { Grossa, nomeado por Mário Tourinho; } \\
\text { Deputado Estadual, 1935-1937. }\end{array}$ \\
\hline
\end{tabular}


Revista NEP - Núcleo de Estudos Paranaenses, Curitiba, v.5, n.1, jun. 2019

\begin{tabular}{|c|c|c|}
\hline $\begin{array}{l}\text { Manoel de Alencar } \\
\text { Guimarães }\end{array}$ & Direito (PE) & $\begin{array}{l}\text { Secretário de estatística, deputado estadual } \\
\text { em 1892, deputado federal em 1894, } \\
\text { reelegendo-se em 1900. Presidente interino } \\
\text { do estado, 1908; Senador por cinco } \\
\text { legislaturas; Fundador e dirigente do Partido } \\
\text { Democrático Paranaense; Deputado } \\
\text { Estadual, 1935-1937. }\end{array}$ \\
\hline $\begin{array}{l}\text { Ulysses } \\
\text { Vieira }\end{array}$ & Direito (PR) & $\begin{array}{l}\text { Fundador e dirigente do Partido Democrático } \\
\text { Paranaense; Deputado Estadual, 1935-1937 }\end{array}$ \\
\hline
\end{tabular}

Fontes: NEGRÃO; OLIVEIRA, 2000, 1997; NICOLAS, 1984; ALEP.

A bancada do PSN na Assembleia Legislativa elegeu 5 deputados estaduais. Os dados prosopográficos indicam que dois deles se formaram em Direito e um tinha formação militar.

Quanto aos dados de carreira política dos deputados estaduais do PSN, constatamos que três deles atuaram decisivamente na Revolução de 1930 no Paraná, sendo eles: Antônio Couto Pereira, Joaquim Pereira de Macedo e Jorge Becher.

Dos cinco deputados, dois começaram as suas carreiras políticas após 1930, sendo eles Antônio Couto Pereira e Ulysses Falcão Vieira. Os outros três deputados do PSN iniciaram suas carreiras políticas na Primeira República, exercendo importantes cargos. Porém, destacamos que dois deles tinham suas carreiras associadas a dissidências políticas, como é o caso de Joaquim Pereira de Macedo e Manoel de Alencar Guimarães.

O Partido Social Nacionalista surgiu como uma legenda de oposição ao governo Manoel Ribas, composto de apoiadores da Revolução de 1930 que não se sentiam representados com os rumos adotados pela interventoria de Ribas. Seus membros eram ligados a figura do antigo interventor do Paraná, Mário Tourinho, nomeado durante os acontecimentos de outubro de 1930, muito em parte devido à influência do seu irmão, Plínio Tourinho, na preparação e eclosão do movimento.

Dados indicam que seus membros fazem parte e exemplificam o processo de modernização conservadora do estado. Três dos cinco integrantes eram membros do principal partido que reunia os oligarcas dissidentes, o Partido Democrático Paranaense. Além disso, Joaquim Pereira de Macedo, Jorge Becher e Manoel de Alencar Guimarães ocupavam cargos políticos no período pré-1930. Os outros dois deputados estaduais, Antônio Couto Pereira e Ulysses Falcão Vieira, começaram as suas carreiras política no período pós-1930.

\section{Considerações Finais}


$\mathrm{Na}$ análise das trajetórias políticas e capitais familiares dos 74 deputados federais e estaduais do Paraná no contexto da Revolução de 1930, constatamos que o conceito de modernização conservadora se aplica no contexto local.

$\mathrm{Na}$ análise dos deputados federais eleitos antes de outubro de 1930 que exerciam mandatos no momento de eclosão da revolução, assinalamos que a sua totalidade pertencia a classe dominante tradicional, com ligações genealógicas correspondentes as principais famílias do estado, e também com chefes políticos locais. A totalidade de deputados federais eleitos tinham propriedades ligadas ao comércio e a agricultura na região do Paraná Tradicional. Todos os quatro possuíam formação superior e também exerciam cargos no executivo e no legislativo paranaense há mais de 10 anos. Estes agentes pertenciam a uma grande rede de dominação política e econômica reproduzida através de relações e laços de parentesco em um grau relativamente homogêneo de organização da classe dominante paranaense. Dos 4 deputados que tiveram seus mandatos atravessados pela Revolução de 1930, somente João Moreira Garcês ocupou cargos políticos após a Revolução de 1930, o que indica uma quebra de poder nesse grupo.

Em relação ao grupo de 10 deputados federais eleitos após a Revolução de 1930, nos pleitos de 1933 e 1934, assinalamos que 6 eram portadores de títulos genealógicos e 2 eram pertencentes a famílias militares. Quanto aos capitais econômicos, 4 deputados ligados a grande propriedade de terras, indústria e comércio e 6 deputados com pertencimento a famílias ligadas a profissões liberais ou ao alto funcionalismo público, civil e militar. Quanto às origens sociais, não houve rupturas significativas. Já em relação aos capitais políticos, verificamos uma renovação na representação federal do estado entre os deputados federais eleitos no período pós-1930. Dos 10 deputados, 9 não tinham exercido cargos antes de 1930. A grande maioria (8 de 10) dos deputados participou ativamente da Revolução de 1930. O PSD é o partido hegemônico na Câmara Federal, elegendo 8 dos 10 deputados. Destes 8 deputados, 3 foram membros do DASP no Estado Novo.

$\mathrm{Na}$ análise dos deputados estaduais que tiveram os seus mandatos atravessados pela Revolução de 1930, assinalamos o seguinte perfil: Dos 28 deputados, 22 nasceram no Paraná Tradicional. Destes 22 paranaenses, 16 eram portadores de títulos genealógicos e 5 pertenciam a famílias com chefes políticos municipais. Dos 28 deputados estaduais, 17 eram 
detentores de propriedades de terras ligadas à agricultura, ao comércio, à criação de gado e à indústria, 7 deputados ligados a altos postos no funcionalismo militar e público, 3 deputados com atuação no grande comércio/indústria. A partir destes dados, conclui-se que o perfil geral dos deputados estaduais do período pré-1930 compõe uma classe dominante aparentada entre si e reativamente homogênea quanto ao acúmulo de capitais.

No que se refere aos capitais políticos, assinalamos que todos os 28 deputados pertenciam ao Partido Republicano. Entre os deputados, 14 possuíam carreiras como chefes políticos municipais. Destes 14 deputados, 10 combinaram suas atividades políticas nos municípios com mais de um ou vários mandatos na ALEP. Tais dados indicam três características da política paranaense no período pré-1930: a predominância do PRP, a influência da municipalidade e dos seus chefes políticos na ocupação de cargos no legislativo e a alta potência da reprodução de poderes no interior da casa legislativa. Essa tendência de continuidade no poder foi atingida pela nova dinâmica política do período pós-1930, pois apenas 2 dos 28 deputados em questão continuaram suas carreiras políticas com o exercício de cargos.

Em relação aos deputados estaduais eleitos em 1935, assinalamos a predominância do PSD no legislativo estadual, elegendo 23 das 33 cadeiras. O perfil genealógico e socioeconômico do PSD revela que dos 23 deputados, 17 nasceram na região do Paraná Tradicional, e destes deputados paranaenses, 14 eram portadores de títulos genealógicos. Quanto a composição social, não houve ruptura com os antigos padrões de dominação verificados no período anterior a revolução de 1930 e nem aos séculos da história política passada. Quanto aos capitais políticos, algumas mudanças foram perceptíveis: apenas 3 dos 23 deputados tinham cargos ou mandatos políticos antes da Revolução de 1930 e 4 dos 23 deputados do PSD tinham cargos em municípios, um número reduzido em relação ao período pré-1930. Isso indica uma redução da influência da municipalidade e dos chefes políticos locais na ocupação de cargos no legislativo estadual e uma renovação política.

A principal novidade que a Revolução de 1930 implantou na república foi o pluralismo político. O PSD sofria oposição de outras duas legendas: a União Republicana Paranaense e o Partido Social Nacionalista. A primeira legenda tinha identificação com o padrão de recrutamento e dominação política do período pré-1930, sendo o chefe desta agremiação o ex-presidente do estado, Caetano Munhoz da Rocha. O perfil genealógico e socioeconômico dos mesmos corrobora com estes argumentos: 4 dos 5 deputados eram 
Revista NEP - Núcleo de Estudos Paranaenses, Curitiba, v.5, n.1, jun. 2019

nascidos no Paraná Tradicional e todos portadores de títulos genealógicos. A ligação com o antigo produto econômico do estado também é verificável nos dados: 3 dos 5 deputados tinham propriedades relacionados ao comércio e a industrialização da erva-mate.

Já a bancada do PSN é formada por lideranças da Revolução de 1930 no Paraná descontentes com os rumos tomados pelo interventor Manoel Ribas, do PSD. No entanto, o perfil social e genealógico da legenda não difere radicalmente dos demais partidos: Dos 5 deputados do PSN, 3 eram portadores de títulos genealógicos e esses três deputados possuíam grandes propriedades ligadas ao comércio, à agricultura e a indústria da erva-mate.

Destacamos a pertinência da verificação biográfica e do levantamento dos capitais acumulados pelos agentes dominantes da política para a análise das mudanças e permanências do processo político de 1930.

\section{Referências}

ALEP. Conheça os deputados. Disponível em: 〈http://www.alep.pr.gov.br/deputados >. Acesso em: 11.fev.2019.

BONNEWITZ, Patrice. Primeiras Lições sobre a sociologia de P. Bourdieu. Petrópolis: Vozes, 2003.

BOURDIEU, Pierre. "O campo político". In Revista Brasileira de Ciência Política, n 5, Brasília, jan-jul de 2011, pp.193-216.

CARNEIRO, David; VARGAS, Túlio. História biográfica da República no Paraná. Curitiba: BANESTADO, 1994.

CASA CIVIL. Eurides Cunha. Disponível em: $<$ http://www.casacivil.pr.gov.br/modules/conteudo/conteudo.php? conteudo=107 >. Acesso em: 31 jan.2019.

CASA CIVIL. Vicente Machado da Silva Lima. Disponível em: $<$ http://www.casacivil.pr.gov.br/modules/conteudo/conteudo.php? conteudo=36>.Acesso em: 11.fev.2019.

DAGOSTIM, Maristela Wessler. A República dos conselhos: um estudo sobre a transformação do perfil da elite política paranaense (1930-1947). Dissertação (Mestrado) - Universidade Federal do Paraná, Setor de Ciências Humanas, Letras e Artes, Programa de Pós-graduação em Ciência Política, 2011. 
DHBB CPDOC FGV. Verbete Otávio da Silveira. Autoria: Vilma Keller. Disponível em: $<$ http://www.fgv.br/cpdoc/acervo/dicionarios/verbete-biografico/silveira-otavio-da>. Acesso em: 15.jun.2018.

DHBB CPDOC FGV. Acir Guimarães. Disponível em: <http://www.fgv.br/cpdoc/acervo/dicionarios/verbete-biografico/guimaraes-acir >. Acesso em: 04.fev.2019.

DHBB CPDOC FGV. Verbete Antônio Jorge Machado Lima. Disponível em: $<$ http://www.fgv.br/cpdoc/acervo/dicionarios/verbete-biografico/lima-antonio-jorgemachado>. Acesso em: 11.fev.2019.

DHBB CPDOC FGV. Verbete Idálio Sardenberg. Disponível em: 〈http://www.fgv.br/cpdoc/acervo/dicionarios/verbete-biografico/sardenberg-idalio >. Acesso em: 11.fev.2019.

DHBB CPDOC FGV. Verbete Moreira Garcez. Assinado por Luciana Pinheiro. Disponível em: $\quad$ https://cpdoc.fgv.br/sites/default/files/verbetes/primeirarepublica/GARCEZ,\%20Jo\%C3\%A3o\%20Moreira.pdf >. Acesso em: 31.jan. 2019.

DHBB CPDOC FGV. Verbete Paula Soares. Disponível em: <http://www.fgv.br/cpdoc/acervo/dicionarios/verbete-biografico/francisco-de-paulasoares-neto >. Acesso em: 09.abr.2019.

DHBB CPDOC FGV. Verbete Plínio Marques. Autoria: Luciana Pinheiro. Disponível em: $<$ https://cpdoc.fgv.br/sites/default/files/verbetes/primeirarepublica/MARQUES,\%20P1\%C3\%ADnio.pdf >. Acesso em: 31.jan.2019.

DICIONÁRIO Histórico- Biográfico Brasileiro. Verbete Plínio Tourinho. Disponível em: <http://www.fgv.br/cpdoc/acervo/dicionarios/verbete-biografico/plinio-alves-monteirotourinho>. Acesso em: 15.jun.2018.

GOULART, Monica Helena Harrich Silva. Classe dominante e jogo político na Assembleia Legislativa paranaense (1889-1930). Tese (doutorado). Universidade Federal do Paraná, Setor de Ciências Humanas, Letras e Artes, Programa de Pós-graduação em Sociologia, 2008.

GOULART, Mônica Helena Harrich Silva. O poder local e o coronelismo no Paraná. Revista NEP (Núcleo de Estudos Paranaenses) Curitiba, v.1, n.1, p. 15-39, dezembro 2015. GOULART, Monica Helena Harrich Silva. Poder local e o coronelismo no Estado do Paraná 1880-1930, Dissertação (Mestrado) - Universidade Federal do Paraná, Setor de Ciências Humanas, Letras e Artes, Programa de Pós-graduação em Sociologia, 2004.

INSTITUTO HISTÓRICO, GEOGRÁFICO E ETNOGRÁFICO PARANAENSE. Cinquentenário da revolução de trinta no Paraná. Curitiba: IHGEP, 1980. 
LAIBIDA, Daiane Carnelos Resende. "Requião tem razão"? Homem político e discursos: um estudo sobre a trajetória política de Roberto Requião de Mello e Silva. Tese. Doutorado em Sociologia. Curitiba, Universidade Federal do Paraná, 2015. Disponível em: <https://acervodigital.ufpr.br/bitstream/handle/1884/41026/R\%20-\%20T\%20\%20DAIANE\%20CARNELOS\%20RESENDE\%20LAIBIDA.pdf? sequence=2\&isAllowe $\mathrm{d}=\mathrm{y}>$. Acesso em: 02.abr.2019.

MONTEIRO, Claudia. Política entre razão e sentimentos: a militância dos comunistas no Paraná (1945-1947). Tese. Doutorado em História. Universidade Federal do Paraná, 2013.

MOORE, Barrington, Jr. As origens sociais da ditadura e da democracia: senhores e camponeses na construção do mundo moderno. Santos: Martins Fontes, 1967.

NEGRÃO, Francisco. Genealogia Paranaense. Volume $1^{\circ}$. Curitiba: Impressora Paranaense, 1926.

NEGRÃO, Francisco. Genealogia Paranaense. Volume $2^{\circ}$. Curitiba: Impressora Paranaense, 1927.

NEGRÃO, Francisco. Genealogia Paranaense. Volume $3^{\circ}$. Curitiba: Impressora Paranaense, 1928.

NEGRÃO, Francisco. Genealogia Paranaense. Volume $4^{\circ}$. Curitiba: Impressora Paranaense, 1929.

NEGRÃO, Francisco. Genealogia Paranaense. Volume $5^{\circ}$. Curitiba: Impressora Paranaense, 1946.

NEGRÃO, Francisco. Genealogia Paranaense. Volume $6^{\circ}$. Curitiba: Impressora Paranaense, 1950.

NICOLAS, Maria. 130 anos de vida parlamentar paranaense -1854-1984. Curitiba, PR: Coordenadoria de Estudos e Promoções Especiais, 1984.

NICOLAS, Maria. O Paraná na Câmara dos Deputados (1853-1977). Curitiba, PR: Imprensa Oficial do Estado do Paraná, 1977.

OLIVEIRA, Ricardo Costa de. Notas sobre a política paranaense no período de 1930 a 1945. Revista de Sociologia e Política, n 91997.

OLIVEIRA, Ricardo Costa de. O silêncio das genealogias: classe dominante e estado no Paraná (1853-1930). Tese. Doutorado em Sociologia. Universidade Estadual de Campinas, 2000.

SOUZA, Maria do Carmo. O processo político-partidário na Primeira República. In: MOTA, Carlos Guilherme (org.). Brasil em perspectiva. Rio de Janeiro: Bertrand Brasil, 2001. 
Revista NEP - Núcleo de Estudos Paranaenses, Curitiba, v.5, n.1, jun. 2019

TEIVE, Hélio A.G. Professor Octávio de Silveira: the pioneer of neurology in the State of Paraná. Arq. Neuro-Psiquiatr. vol.66 no.3a São Paulo Sept. 2008.

TOURINHO, Luiz Carlos Pereira. Toiro passante III: tempo de República Velha. Curitiba: Gráfica Editora Rocha, 1990.

Recebido em: 20 maio 2019.

Aceito em: 10 jun. 2019. 